\title{
Synthesis and characterization of fluorescent probes for the development of a ceramide synthase FRET-based assay
}

Eduardo Izquierdo, ${ }^{\text {ab }}$ Mireia Casasampere, ${ }^{\mathrm{a}}$ Gemma Fabrias, ${ }^{\mathrm{a}}$ José Luís Abad, ${ }^{\mathrm{a}}$ Josefina Casas, ${ }^{* a}$ and Antonio Delgado*ab

a) Research Unit on BioActive Molecules. Department of Biological Chemistry. Institute for Advanced Chemistry of Catalonia (IQAC-CSIC). Jordi Girona 18. 08034-Barcelona, Spain

b) Department of Pharmacology, Toxicology and Medicinal Chemistry, Unit of Pharmaceutical Chemistry (Associated Unit to CSIC). Faculty of Pharmacy. University of Barcelona. Avda. Joan XXIII s/n, 08028 Barcelona, Spain

\begin{abstract}
Ceramides are recognized to occupy a pivotal position in sphingolipid metabolism, playing a fundamental role as membrane structural components, as well as second messengers. Ceramide synthases (CerS) are a family of enzymes that catalyze the $N$-acylation of sphingosine and dihydrosphingosine, thus controlling the levels of intracellular ceramides. In this work, we present the synthesis and the fluorescent properties of new probes for the development of a FRET-based assay for CerS activity. Based on our previous discovery of spisulosine as a suitable probe for CerS activity in cells, the use of a modified NBD-spisulosine with a clickable fatty acid as CerS substrates may allow the ultimate formation of a bichromophoric reporter for a FRET-based analysis of CerS activity in cells.
\end{abstract}




\section{Introduction}

Sphingolipids (SLs) are one of the major classes of lipids in eukaryotes. Canonical SLs derive from the sphingoid base dihydrosphingosine (dhSo) or $(2 R, 3 S)$ 2-amino-1,3-octadecanediol, which is metabolically modified to account for the different families of SLs known to date. ${ }^{1}$ Among them, ceramides (Cer), arising from the formal $N$-acylation and 4,5-desaturation of dhSo, occupy a pivotal position of the metabolic pathways. ${ }^{2}$ Apart from their fundamental structural role in cell membranes, ${ }^{3}$ Cer are also important second messengers. In this regard, Cer have been reported to activate apoptosis in response to a variety of cell stress inducing agents. ${ }^{4-6}$ Likewise, various types of cancer cells have been shown to reduce their Cer levels as a survival strategy through the overexpression of CDase enzymes. ${ }^{7}$ Furthermore, Cer also participate in the regulation of autophagy, and stimulate cell cycle arrest, cell differentiation, ${ }^{8}$ and senescence. ${ }^{9}$

The intracellular levels of Cer are the result of the catabolic processes from higher SLs (sphingomyelin, glycosphingolipids and ceramide-1-phosphate), as well from the biosynthesis de novo by the $N$-acylation of dhSo with a variety of fatty acids, prior to their desaturation by a specific desaturase (Des1), which introduces a $\mathrm{C} 4(E)$ double bond into the sphingoid base. In this context, ceramide synthases (CerS) are a family of enzymes responsible for the $N$-acylation of dhSo (in the de novo pathway) or sphingosine (So) (in the catabolic pathway) to form dhCer and Cer, respectively (Scheme 1). ${ }^{10}$

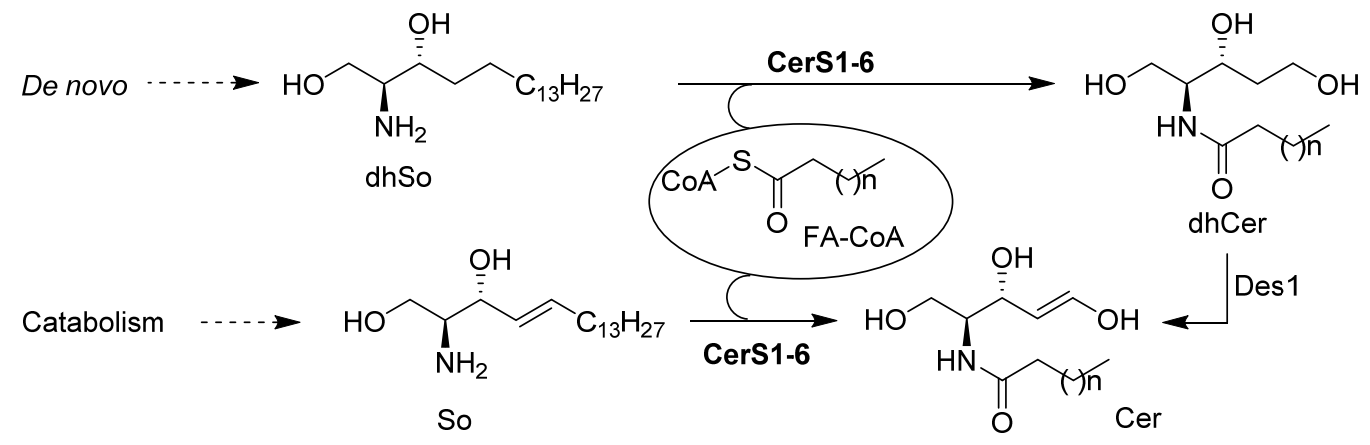

Scheme 1. Metabolic routes leading to Cer

Six isoforms of CerS have been identified in mammals, each one encoded by a unique gene (CerS1-6). ${ }^{11}$ CerS enzymes are expressed differently in various tissues ${ }^{12}$ and their levels of expression change during development, suggesting that populations of Cer with particular acyl chain lengths might be generated to meet the specific physiological needs of each tissue. ${ }^{13}$ Moreover, the nature of the acyl chains is determinant for the biophysical properties of the 
resulting Cer and also for the signalling pathways they participate. ${ }^{14}$ The development of modern lipidomic techniques ${ }^{15}$ has allowed to determine the relative abundance of the various Cer species in a range of biological contexts, and has provided some insight into the effect of the acyl chain composition on the physiological role of Cer. ${ }^{16}$ Given the importance of CerS activity in cell fate, we became interested in the development of new chemical probes ${ }^{17}$ towards this end. In a previous work, we reported on the use of 1-deoxydihydrosphingosine (doxdhSo, spisulosine or ES285) as a suitable probe for the profiling of CerS activity in intact cells. ${ }^{18}$ On the basis that 1-deoxysphingolipids (doxSLs) can be virtually considered as "dead-end" metabolites due to the lack of the $\mathrm{C} 1-\mathrm{OH}$ group, we envisioned that a fluorescent probe derived from spisulosine, together with a suitable fatty acid analogue, could be used to develop a FRET-based assay to monitor CerS activity.

\section{Objectives}

Given the roles of CerS in cells, the discovery of new tools to monitor its activity becomes of interest to decipher the molecular mechanisms underlying these processes. For this reason, we are interested in the development of a FRET-based fluorescence assay to determine the activity of CerS, following the general experimental design depicted in Scheme 2.
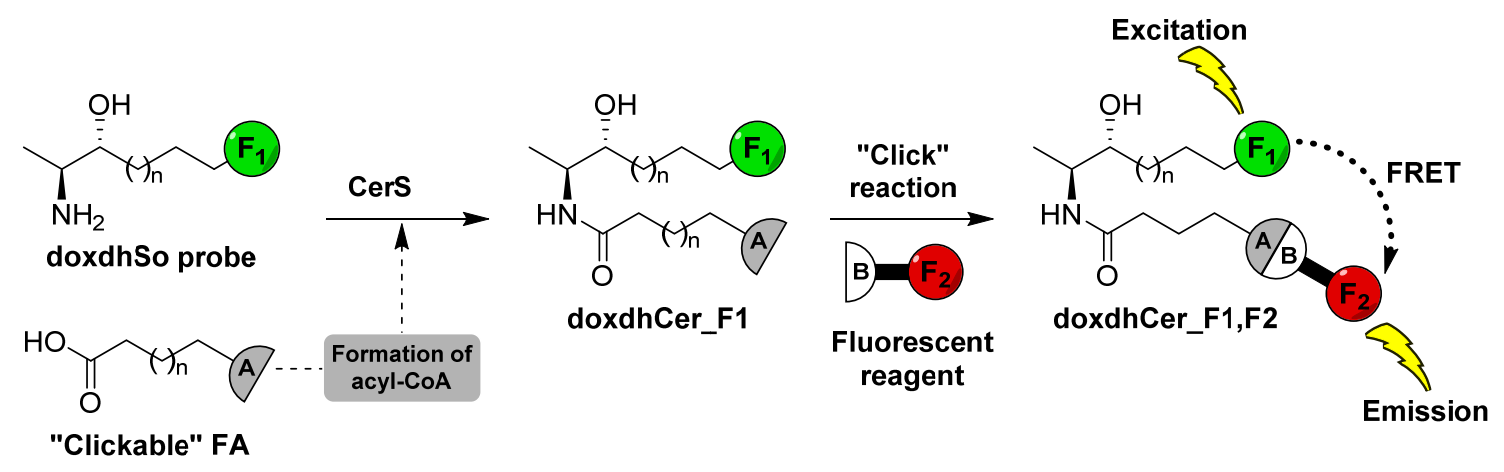

Scheme 2. Schematic representation of the proposed FRET-based CerS activity assay.

A fluorescently labelled doxdhSo probe and a clickable FA analogue will be sequentially added to cells. Inside the cell, upon the endogenous activation of the FA analogue as a FA-CoA, the two compounds should be enzymatically conjugated by CerS to generate the corresponding doxdhCer_F1. Subsequently, it should be possible to fluorescently label the acyl chain of the doxdhCer molecule by means of a bioorthogonal reaction with a suitable fluorescent reagent. In the bichromophoric doxdhCer molecule, if the two fluorescent groups F1 and F2 are close 
enough, upon excitation of the donor, fluorescence emission from the acceptor should be detected, due to FRET. Therefore, by measuring the differences in fluorescence emission arising from FRET we should be able to determine the activity of CerS. Groups A and B, in doxdhCer_F1 and in the fluorescent reagent, must be mutually reactive bioorthogonal groups. Thus, F1 and F2 must be two fluorophores with matching spectral properties, so they form a donor-acceptor FRET pair.

Based on this general scenario, we report on the synthesis and fluorescent properties of the NBD-labelled doxdhSo RBM5-155 and a series of $\omega$-functionalized fatty acids as potential CerS substrates. The resulting doxdhCer would be amenable to render bioorthogonal click reactions with suitable fluorescent reagents (see Figure 1). Thus, a small collection of differently functionalized fatty acids of diverse chain lengths, together with some suitable reactive partners for bioorthogonal copper-free click reactions (tetrazines for alkenes and bicyclononynes (BCN) for azides) have been synthesized. In addition, the expected CerS metabolites arising from condensation of the NBD probe RBM5-155 with the $\omega$-azido fatty acid RBM5-065, together with their corresponding click adducts with the BCN-derived fluorescent reagents RBM5-142 and RBM5-143 have also been synthesized as standards for the assay development that is currently underway in our laboratory.

A. Spisulosine-based 1-doxdhSo probes<smiles>CCCCCCCNc1ccc([N+](=O)[O-])c2nonc12</smiles>

RBM5-155

C. Fluorescent reagents
B. FA analogues

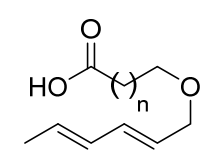

RBM5-029, $n=4$ RBM5-035, $n=6$ RBM5-044, $n=9$

$$
\text { RBM5-068, n=11 RBM5-097 }
$$$$
\text { RBM5-065, } n=14
$$

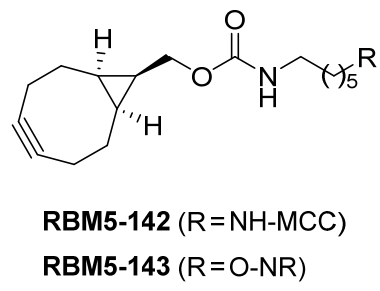

RBM5-139 $(\mathrm{R}=\mathrm{NH}-\mathrm{MCC})$ RBM5-140 (R=O-NR)

Figure 1. Overview of the different spisulosine-based doxdhSo probes, FA analogues and fluorescent reagents synthesized in this section. NR: Nile red; MCC: 7-methoxycoumarin-3-carboxylic acid 


\section{Results and Discussion.}

\section{Synthesis of the probes}

\section{a) Synthesis of the spisulosine-NBD RBM5-155}

The synthesis of the NBD probe RBM5-155 was carried out as depicted in Scheme 3. Starting from the anti-configured allylic alcohol RBM5-084,,${ }^{19}$ an intermolecular Grubbs' secondgeneration catalyzed olefin metathesis with bromoalkene RBM5-149 ${ }^{20}$ afforded a highly $E$ enriched $E: Z$ mixture (RBM5-150), in agreement with the literature. ${ }^{19}$ This mixture was subjected to catalytic hydrogenation on $\mathrm{Rh} / \mathrm{Al}_{2} \mathrm{O}_{3}$ to give the corresponding saturated $\omega$-bromo intermediate RBM5-151. Subsequent nucleophilic displacement of the bromine atom with sodium azide furnished RBM5-152. Reduction of the azido group with the $\mathrm{Pd} / \mathrm{C}-\mathrm{TES}$ system $^{21}$, followed by reaction of the intermediate amine hydrochloride RBM5-153 with $\mathrm{NBD}-\mathrm{Cl},{ }^{22}$ and $N$-Boc removal afforded probe RBM5-155, which was isolated and further manipulated as the corresponding hydrochloride, given its apparent sensitivity to the alkaline conditions required for the formation of the free amine. ${ }^{23}$ Finally, $N$-acylation of RBM5-155 with $\omega$-azidopalmitic acid RBM5-165 afforded the doxdhCer RBM5-159, which was required as standard for quantitative lipidomics (LC-MS) assays.

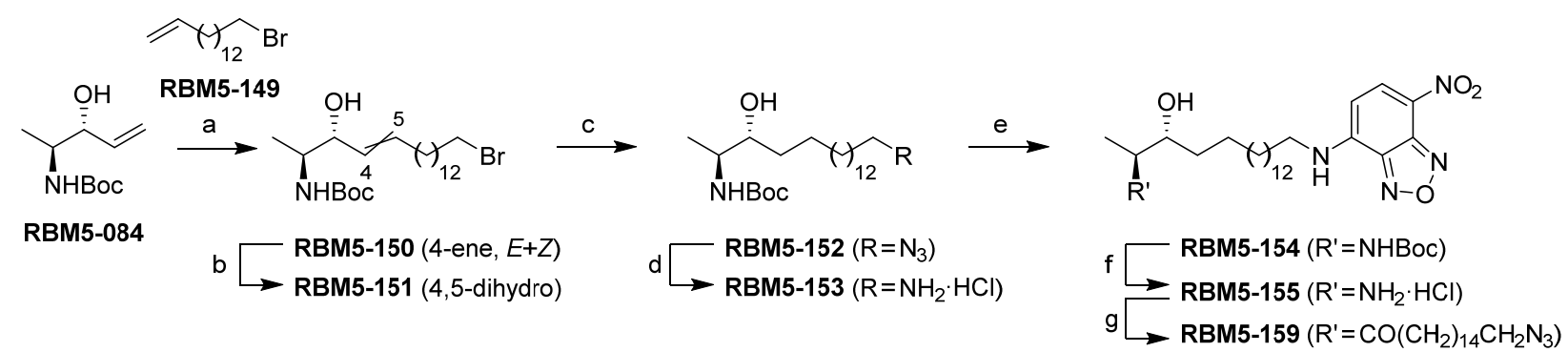

Scheme 3. Synthesis of doxSL probes. Reagents and conditions: (a) RBM5-149, Grubbs' 2nd gen. catalyst, $\mathrm{CH}_{2} \mathrm{Cl}_{2}$, reflux, $2 \mathrm{~h}, 44 \%, E / Z=95: 5$; (b) $\mathrm{H}_{2}, 5$ wt. \% Rh on $\mathrm{Al}_{2} \mathrm{O}_{3}, \mathrm{MeOH}, \mathrm{rt}, 3 \mathrm{~h}, 86 \%$; (c) $\mathrm{NaN}_{3}, \mathrm{DMF}, 80^{\circ} \mathrm{C}, 3$ h, 95 \%; (d) TES, Pd-C, $\mathrm{MeOH}: \mathrm{CHCl}_{3}$ (9:1), rt, 10 min, 85 \%; (e) NBD-Cl, DIPEA, $\mathrm{MeOH}, 0{ }^{\circ} \mathrm{C}$ to rt, overnight, $84 \%$; (f) $\mathrm{AcCl}, \mathrm{MeOH}, 0{ }^{\circ} \mathrm{C}$ to rt, overnight, $80 \%$ (RBM5-155); (g) EDC, $\mathrm{HOBt}, \mathrm{Net}_{3}, \mathrm{CH}_{2} \mathrm{Cl}_{2}, \mathrm{rt}, 2$ h, $74 \%$

\section{b) Synthesis of the fatty acid analogues}

\section{b1) Diene-tagged fatty acids}

As shown in Scheme 4, the reaction between the in situ generated lithium acetylide of propargyl alcohol with 7-bromoheptane afforded the internal alkyne RBM5-036. Subsequent 
isomerization of the triple bond with freshly prepared KAPA furnished the $\omega$-alkynol RBM5-038. ${ }^{24}$ The hydroxyl function was then replaced with a bromide through an Appel-type reaction, followed by the oxidative cleavage of the terminal alkyne with $\mathrm{KMnO}_{4}$ to provide the intermediate RBM5-041. This carboxylic acid was refluxed in $\mathrm{MeOH}$, in the presence of catalytic $\mathrm{H}_{2} \mathrm{SO}_{4}$, to yield the corresponding $\omega$-bromo methyl ester RBM5-042, which was spectroscopically in agreement with the literature. ${ }^{25}$

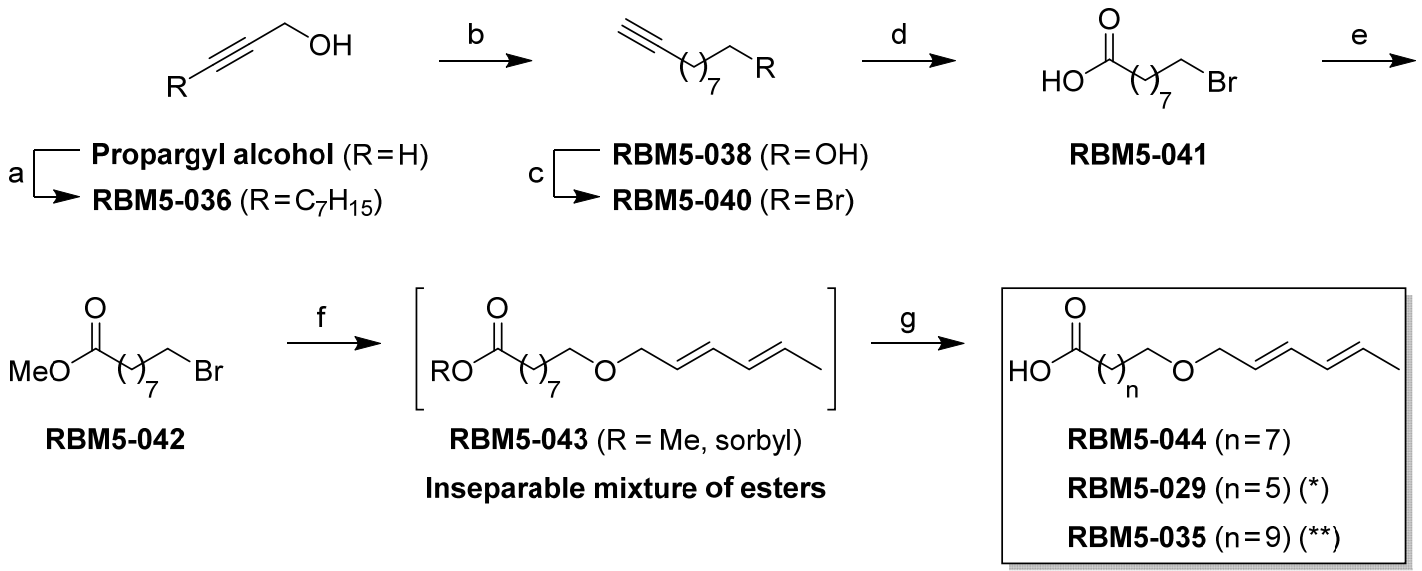

Scheme 4. Synthesis of the diene-tagged FAs RBM5-029, RBM5-035 and RBM5-44. Reagents and conditions: (a) (i) $n$-BuLi, THF, HMPA, $-78{ }^{\circ} \mathrm{C}$ to $-30{ }^{\circ} \mathrm{C}, 30 \mathrm{~min}$. (ii) 7-bromoheptane, $-30{ }^{\circ} \mathrm{C}$ to rt, overnight, $45 \%$; (b) Li, $\mathrm{KO} t \mathrm{Bu}$, 1,3-diaminopropane, $70{ }^{\circ} \mathrm{C}$ to rt, 3 h, $72 \%$; (c) NBS, $\mathrm{PPh}_{3}, \mathrm{DMF}, 0{ }^{\circ} \mathrm{C}$ to rt, $1 \mathrm{~h}, 86 \%$; (d) $\mathrm{KMnO}_{4}, \mathrm{CTAB}, \mathrm{H}_{2} \mathrm{O} / \mathrm{CH}_{2} \mathrm{Cl}_{2} / \mathrm{AcOH}$ (10:4:1), $0{ }^{\circ} \mathrm{C}$ to rt, overnight, $98 \%$; (e) $\mathrm{H}_{2} \mathrm{SO}_{4}$, $\mathrm{MeOH}$, reflux, 4 h, 88-98 \%; (f) Sorbyl alcohol, NaH, NaI, DMF, $0{ }^{\circ} \mathrm{C}$ to rt, 3 h; (g) LiOH, THF/ $\mathrm{H}_{2} \mathrm{O}$ (3:1), $0{ }^{\circ} \mathrm{C}, 2 \mathrm{~h}, 34 \%$ (over two steps).

Several reaction conditions were assessed for the Williamson etherification reaction. However, even under the optimized conditions, the desired etherification was accompanied by a partial transesterification to an inseparable mixture of esters that uneventfully underwent alkaline hydrolysis to deliver the desired $\omega$-dienic carboxylic acid RBM5-044. Similarly, the dienic acids RBM5-029 and RBM5-035 were synthesized from commercially available 7-bromoheptanoic acid and 11-dodecynol.

\section{b2) Azide-tagged fatty acids}

Even though many azido-functionalized lipids have already been described in the literature, ${ }^{26-}$

31 it is still unclear how the azido group emulates a carbon chain, and authors often differ in whether the nitrogen atoms of the azide should or should not be counted when designing an 
$\omega$-azido fatty acid analogue of a particular chain length. Therefore, both RBM5-065 and RBM5-068 were synthesized as potential palmitic acid surrogates, as shown in Scheme 5.
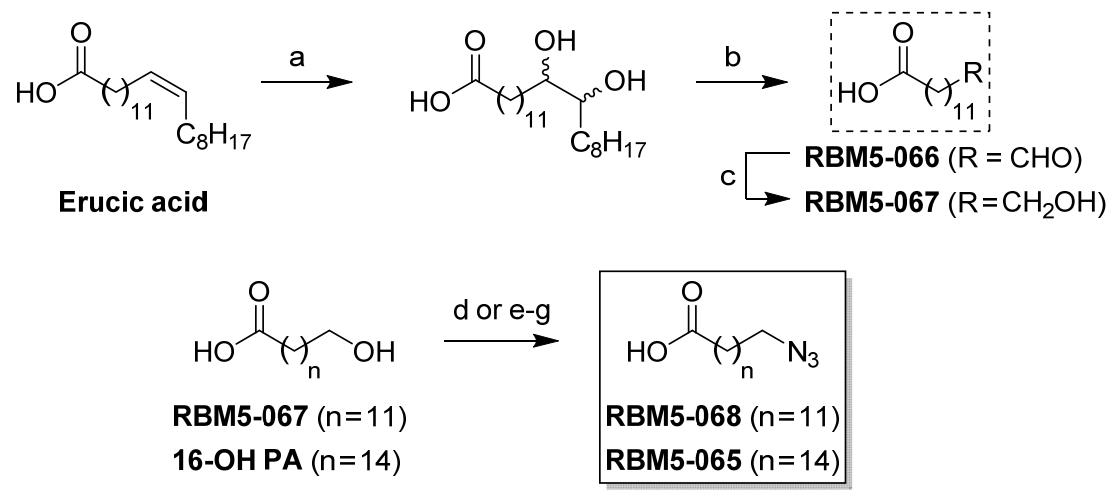

Scheme 5. Synthesis of the terminal azide-tagged FAs RBM5-065 and RBM5-68. Reagents and conditions: (a) (i) $\mathrm{H}_{2} \mathrm{O}_{2}, \mathrm{HCOOH}$, rt, overnight; (ii) $\mathrm{KOH}, \mathrm{H}_{2} \mathrm{O}$, rt , overnight (b) $\mathrm{NaIO}_{4}, \mathrm{CHCl}_{3}, \mathrm{H}_{2} \mathrm{O}$, rt, overnight, 67 \% (over three steps); (c) $\mathrm{NaBH}_{4}, \mathrm{EtOH}, \mathrm{rt}, 2 \mathrm{~h}, 85 \%$; (d) (i) $\mathrm{NBS}, \mathrm{PPh}_{3}, \mathrm{DMF}, 0{ }^{\circ} \mathrm{C}$ to rt, 1 h, (ii) $\mathrm{NaN}_{3}$, DMF, $80{ }^{\circ} \mathrm{C}, 3 \mathrm{~h}, 59$ \% (over two steps) (RBM-068). For RBM5-065: (e) $\mathrm{H}_{2} \mathrm{SO}_{4}$, $\mathrm{MeOH}$, reflux, 4 h, 78 \%; (f) DPPA, DBU, DMF, rt, overnight, $81 \%$; (g) LiOH, THF : $\mathrm{H}_{2} \mathrm{O}(3: 1), 0{ }^{\circ} \mathrm{C}$, $2 \mathrm{~h}, 78 \%$

Starting from erucic acid ( EError! No se encuentra el origen de la referencia.), epoxidation using hydrogen peroxide, followed by the alkaline ring opening, ${ }^{32}$ gave a mixture of diastereomeric vicinal diols that was directly subjected to pinacol cleavage with $\mathrm{NaIO}_{4}$ to furnish RBM5-066 in $67 \%$ yield over three steps. Subsequent hydride reduction of the aldehyde group gave the corresponding $\omega$-hydroxyacid RBM5-067. ${ }^{33}$ Finally, the primary alcohol was sequentially treated with $\mathrm{NBS}, \mathrm{PPh}_{3}$ and $\mathrm{NaN}_{3}$ in $\mathrm{DMF}$ to form the $\omega$-azido derivative RBM5-068.

On the other hand, commercial 16-hydroxypalmitic acid was converted into the corresponding methyl ester RBM5-063 by means of standard protocols. Subsequently, the reaction with diphenylphosphoryl azide (DPPA) in the presence of DBU, ${ }^{34}$ followed by the alkaline hydrolysis of the ester delivered the remaining azide-tagged fatty acid RBM5-065 ${ }^{30}$.

\section{b3) Alkene-tagged fatty acids}

Initially, we envisioned that the partial hydrogenation of the triple bond in RBM5-053 (Scheme6, step e) using Lindlar's catalyst would be the most direct way to access the $\omega$-alkene FA RBM5-097. However, as previously reported by Crombie et al., ${ }^{35}$ this methodology is far from optimal. First, reaction completion could not be achieved, even after long reaction times 
and using high catalyst loadings, as determined by the observation in the ${ }^{1} \mathrm{HNMR}$ spectrum of a persistent triplet signal at $2.18 \mathrm{ppm}$, corresponding to the terminal alkyne $\mathrm{CH}$. Moreover, the formation of a small amount of the fully saturated by-product was unavoidable, as evidenced by the appearance of a triplet at $0.88 \mathrm{ppm}$ in the ${ }^{1} \mathrm{H}$ NMR spectrum, corresponding to the terminal $\mathrm{CH}_{3}$. The reaction, thus, produced mixtures of RBM5-097, palmitic acid and unreacted RBM5-053, which were impossible to separate, even as the corresponding methyl esters, in different solvent systems. Taking all the above in consideration, we soon decided to change our strategy to rely on the base-promoted elimination of an appropriate terminal haloalkane, as reported by Hostetler et al. ${ }^{20}$ Hereby, commercially available 16-hexadecanoic acid was converted into the corresponding methyl ester RBM5-063 under typical Fischer esterification conditions. Subsequent iodination of the primary alcohol using NIS/ $\mathrm{PPh}_{3}$ gave the $\omega$-iodoester RBM5-098 in excellent yields. As expected, the treatment with an excess of $\mathrm{KO} t$-Bu resulted both in the elimination of HI and the transesterification of the methyl ester to form RBM5-099. Finally, the acid-mediated removal of the tert-butyl ester group delivered the desired alkenyl FA RBM5-097.

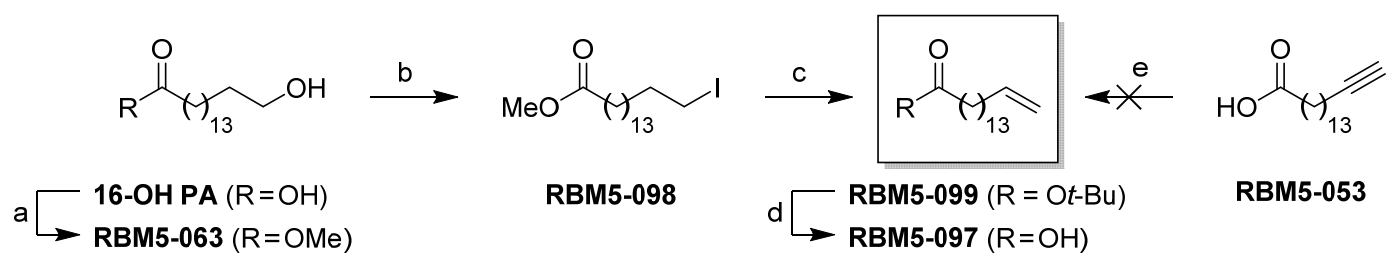

Scheme 6. Synthesis of the terminal alkene FA RBM5-097. Reagents and conditions: (a) $\mathrm{H}_{2} \mathrm{SO}_{4}, \mathrm{MeOH}$, reflux, overnight, $93 \%$; (b) NIS, $\mathrm{PPh}_{3}, \mathrm{CH}_{2} \mathrm{Cl}_{2}, 0{ }^{\circ} \mathrm{C}$ to rt, overnight, $98 \%$; (c) $\mathrm{KO} t \mathrm{Bu}, \mathrm{THF}, \mathrm{rt}, 3 \mathrm{~h}, 78$ $\%$; (d) TFA : $\mathrm{CH}_{2} \mathrm{Cl}_{2}(1: 1), 0{ }^{\circ} \mathrm{C}$ to rt, $2 \mathrm{~h}, 84 \%$; (e) $\mathrm{H}_{2}, \mathrm{Pd}_{-} \mathrm{CaCO}_{3}$-quinoline, EtOAc, rt, $2 \mathrm{~h}$.

\section{c) Synthesis of tetrazine and $\mathrm{BCN}$-derived fluorescent reagents}

\section{c1) Synthesis of the fluorescent moiety}

As summarized in Scheme 7, the synthesis of the fluorescent reagents was envisioned by condensation of the fluorescent moieties RBM5-121, RBM5-135 and RBM5-136 with the appropriate tetrazine or bicyclononyne scaffolds. 


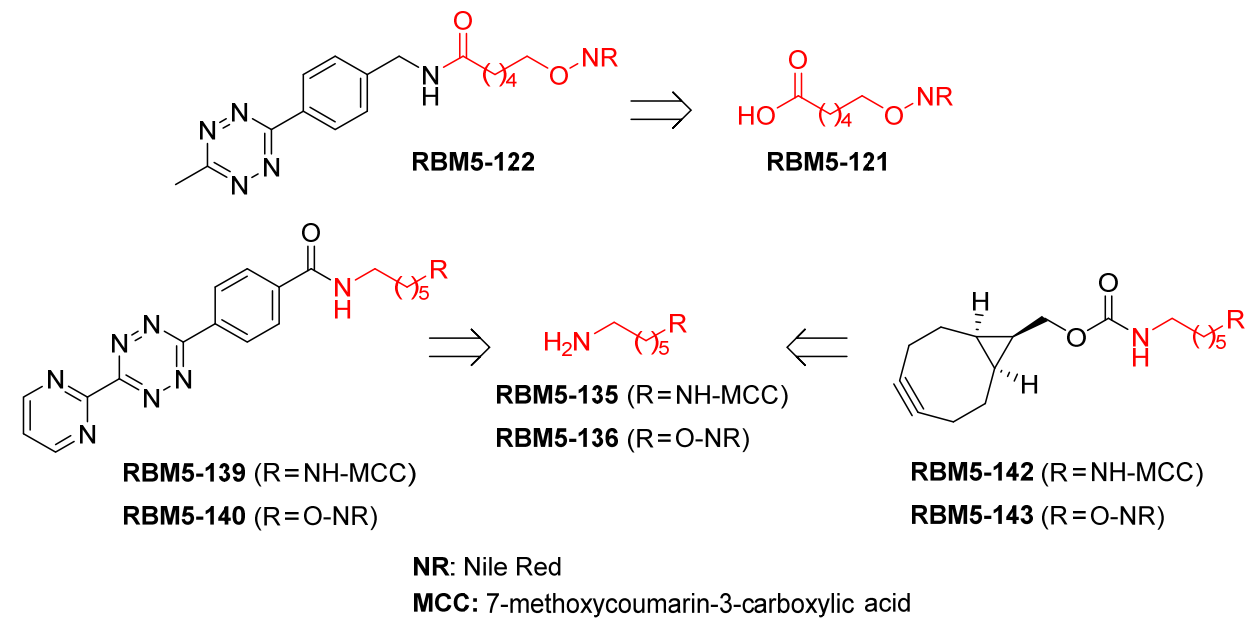

Scheme 7. General strategy for the synthesis of the fluorescent reagents

The synthesis of the precursors RBM5-121 and RBM5-136 (Scheme 8 ) began with the preparation of Nile red, as reported by Yang et al. ${ }^{36} \mathrm{Next}$, the nucleophilic displacement of the bromide group in either tert-butyl 6-bromohexanoate or $N$-Boc-6-bromohexanamine by the potassium phenoxide of RBM5-133 furnished the ethers RBM5-120 and RBM5-136, respectively. Further acidic treatment delivered the corresponding unprotected precursors RBM5-121 and RBM5-136.TFA in excellent yields (Scheme 8). As expected, the EDC-HOBt amide coupling between 7-methoxycoumarin-3-carboxylic acid and $N$-Boc1,6-hexanediamine, followed by the TFA-mediated removal of the Boc amino protecting group gave the remaining amine precursor RBM5-135 $\cdot$ TFA.

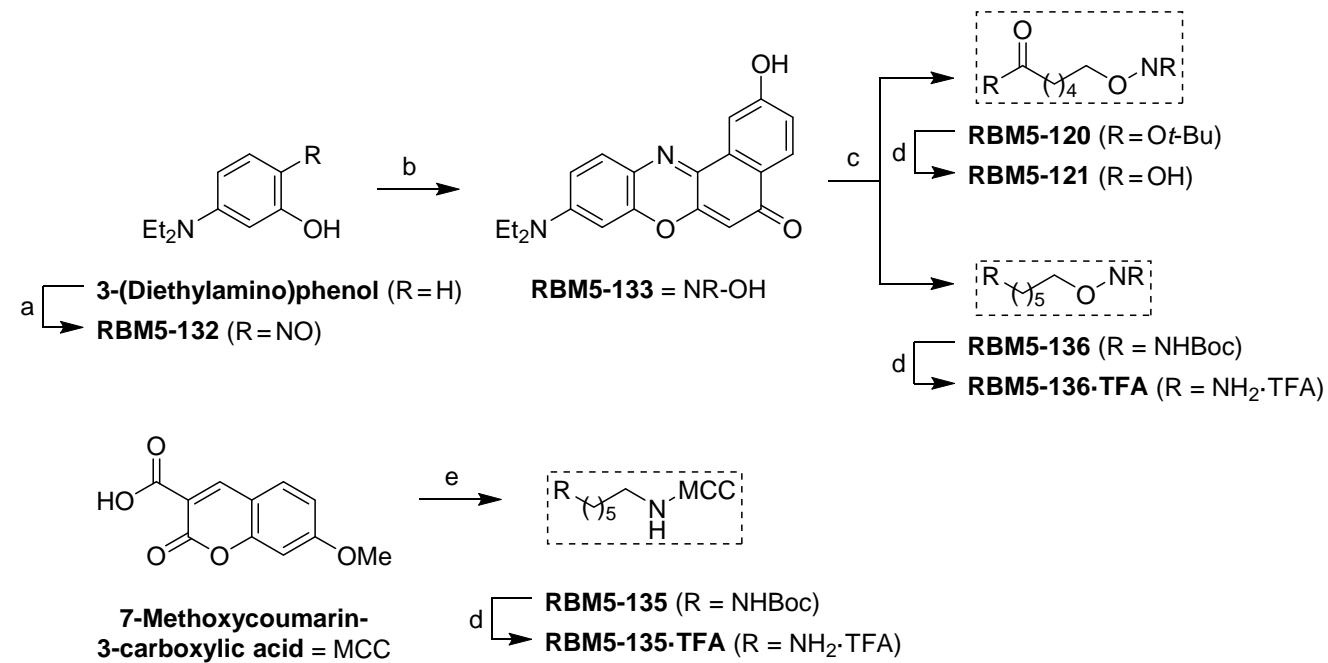

Scheme 8. Synthesis of the precursors RBM5-121, RBM5-135 and RBM5-136. Reagents and conditions: (a) $\mathrm{NaNO}_{2}, \mathrm{HCl}$ (aq.), $0{ }^{\circ} \mathrm{C}, 5 \mathrm{~h}, 67$ \%; (b) naphthalene-1,6-diol, DMF, $160{ }^{\circ} \mathrm{C}, 4 \mathrm{~h}, 19 \%$; (c) For RBM5-136, $N$-Boc-6-bromohexanamine, $\mathrm{K}_{2} \mathrm{CO}_{3}$, DMF, $85^{\circ} \mathrm{C}$, overnight, $78 \%$; for RBM5-120, 
tert-butyl 6-bromohexanoate, $\mathrm{K}_{2} \mathrm{CO}_{3}$, DMF, $85{ }^{\circ} \mathrm{C}$, overnight, $82 \%$; (d) TFA : $\mathrm{CH}_{2} \mathrm{Cl}_{2}(1: 2), 0{ }^{\circ} \mathrm{C}$ to rt, 1 h, quantitative; (e) $\mathrm{N}$-Boc-1,6-hexanediamine, EDC, $\mathrm{HOBt}, \mathrm{NEt}_{3}, \mathrm{CH}_{2} \mathrm{Cl}_{2}, \mathrm{rt}, 2 \mathrm{~h}, 57 \%$

\section{c2) Synthesis of the tetrazines RBM5-122, RBM5-139, and RBM5-140}

The synthesis of RBM5-122 (Scheme 9) began with the treatment of 4-cyanobenzylamine hydrochloride with Boc anhydride in the presence of TEA to give the protected amine RBM5116, which was reacted with acetonitrile and hydrazine hydrate under Ni catalysis to form the 1,2,4,5-tetrazine RBM5-117. ${ }^{37,38}$ The formation of the unwanted symmetrical diaryl tetrazine was avoided by using an excess of acetonitrile. This resulted in the production of a substantial amount of the symmetrical dimethyl tetrazine, which could be easily removed taking advantage of its high volatility. ${ }^{39}$ Subsequent removal of the tert-butyl carbamate moiety under acidic conditions, followed by an amide coupling with the carboxylic acid RBM5-121 using EDC and HOBt as the coupling agents delivered the first tetrazine-based fluorescent reagent RBM5-122.
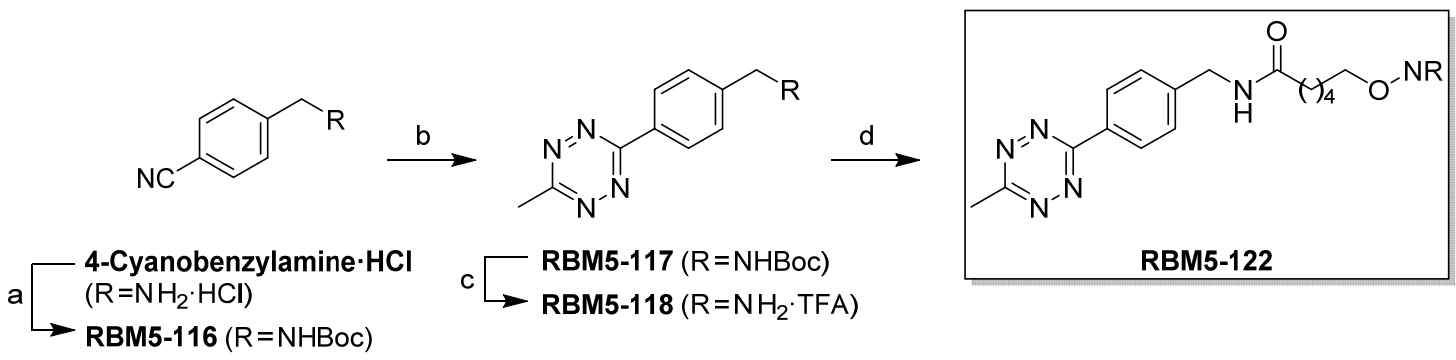

Scheme 9. Synthesis of the tetrazine-based fluorescent reagent RBM5-122. Reagents and conditions: (a) $\mathrm{Boc}_{2} \mathrm{O}, \mathrm{NEt}_{3}, \mathrm{CH}_{2} \mathrm{Cl}_{2}, 0{ }^{\circ} \mathrm{C}$ to rt, overnight, $98 \%$; (b) (i) $\mathrm{ACN}, \mathrm{NiCl}_{2}$, hydrazine hydrate, $60{ }^{\circ} \mathrm{C}$, overnight, (ii) $\mathrm{NaNO}_{2}, \mathrm{HCl}$ (aq.), $0{ }^{\circ} \mathrm{C}, 2 \mathrm{~h}, 49 \%$; (c) TFA : $\mathrm{CH}_{2} \mathrm{Cl}_{2}(1: 1), 0{ }^{\circ} \mathrm{C}$ to rt, $2 \mathrm{~h}, 96 \%$; (d) RBM5-121, EDC, HOBt, $\mathrm{NEt}_{3}, \mathrm{CH}_{2} \mathrm{Cl}_{2}, \mathrm{rt}, 2 \mathrm{~h}, 44 \%$.

The preparation of the remaining tetrazines was carried out as reported by Beckmann et al ${ }^{40}$ (Scheme 10). Thereby, 4-cyanobenzoic acid, 2-cyanopyrimidine and hydrazine hydrate were refluxed in $\mathrm{EtOH}$, without the use of any metal catalyst, to produce a mixture of tetrazines that, in this case, required a much more elaborated work-up to isolate the desired asymmetric tetrazine RBM5-137. Next, the carboxylic acid was converted into the corresponding activated $N$-hydroxysuccinimidyl ester RBM5-138, which readily underwent an addition-elimination reaction with the amines RBM5-135 TFA and RBM5-136-TFA, upon addition of triethylamine, to provide the desired dyes RBM5-139 and RBM5-140. The low isolated yield 
observed for RBM5-139 was due to its poor solubility in a wide range of organic solvents, which caused a low recovery during the work-up and chromatographic purification steps.

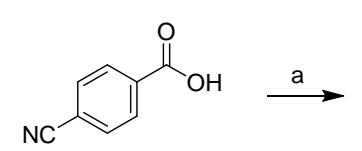

4-Cyanobenzoic acid

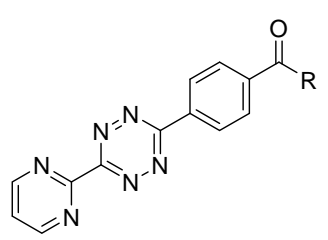

$\mathrm{b} \longrightarrow$ RBM5-137 $(\mathrm{R}=\mathrm{OH})$

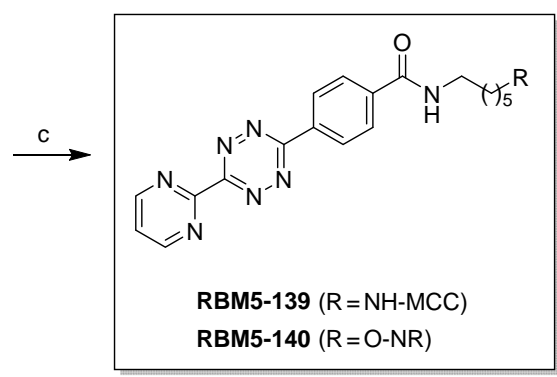

Scheme 10. Synthesis of the tetrazine-based fluorescent dyes RBM5-139 and RBM5-140. Reagents and conditions: (a) (i) 2-cyanopyrimidine, hydrazine hydrate, EtOH, reflux, overnight, (ii) $\mathrm{NaNO}_{2}, \mathrm{AcOH}$, $0{ }^{\circ} \mathrm{C}, 2$ h, $21 \%$; (b) HOSu, EDC, DMSO, pyridine, $40{ }^{\circ} \mathrm{C}, 3$ h, $80 \%$; (c) For RBM5-139: RBM5135·TFA, $\mathrm{NEt}_{3}, \mathrm{CH}_{2} \mathrm{Cl}_{2}$, rt, overnight, $25 \%$; RBM5-140 was obtained from RBM5-136·TFA following the same procedure (95\%).

\section{c3) Synthesis of the bicyclononynes RBM5-142 and RBM5-143}

Both BCN-based fluorescent reagents RBM5-142 and RBM5-143 were obtained in excellent yields by reaction of the amine precursors RBM5-135 TFA and RBM5-136-TFA with the $p$-nitrophenyl carbonate mixed ester RBM5-141 ${ }^{41}$ (Scheme 11). These compounds were spectroscopically characterized in DMSO- $d_{6}$, since a substantial decomposition of the cycloalkyne moiety was noticed when using $\mathrm{CDCl}_{3}$.

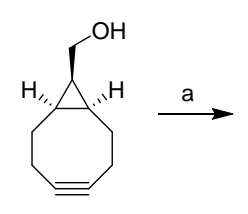

BCN-OH

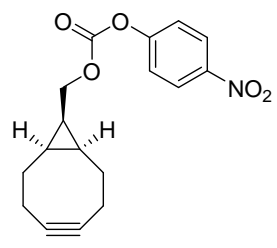

RBM5-141

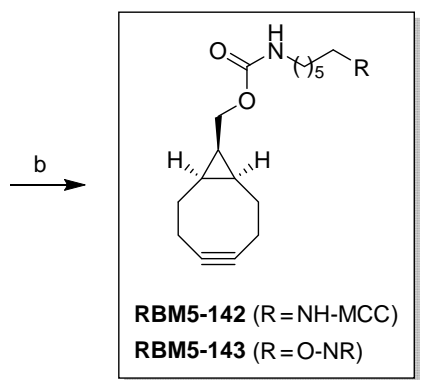

RBM5-142 $(\mathrm{R}=\mathrm{NH}-\mathrm{MCC})$

Scheme 11. Synthesis of the BCN-based fluorescent reagents RBM5-142 and RBM5-143. Reagents and conditions: (a) 4-nitrophenyl chloroformate, pyridine, $\mathrm{CH}_{2} \mathrm{Cl}_{2}$, rt, 30 min, 84 \%; (b) For RBM5142: RBM5-135 $\cdot$ TFA, $\mathrm{NEt}_{3}, \mathrm{CH}_{2} \mathrm{Cl}_{2}$, rt, overnight, $89 \%$; RBM5-143 was obtained from RBM5136-TFA and RBM5-141 following the same procedure ( $90 \%$ ).

\section{d) Synthesis of doxdhCer by SPAAC reactions}

The expected click adducts arising from the condensation of the NBDdoxCer RBM5-159 with the fluorescent reagents RBM5-142 and RBM5-143 were also prepared for their complete 
photochemical characterization and FRET studies, as well as standards for LC-MS quantification in the cell assay optimization. They were obtained by a strain-promoted alkyne-azide cycloaddition (SPAAC) reaction between NBDdoxdhCer RBM5-159 and the fluorescent reagents RBM5-142 (MCC) and RBM5-143 (NR) (Scheme 12).

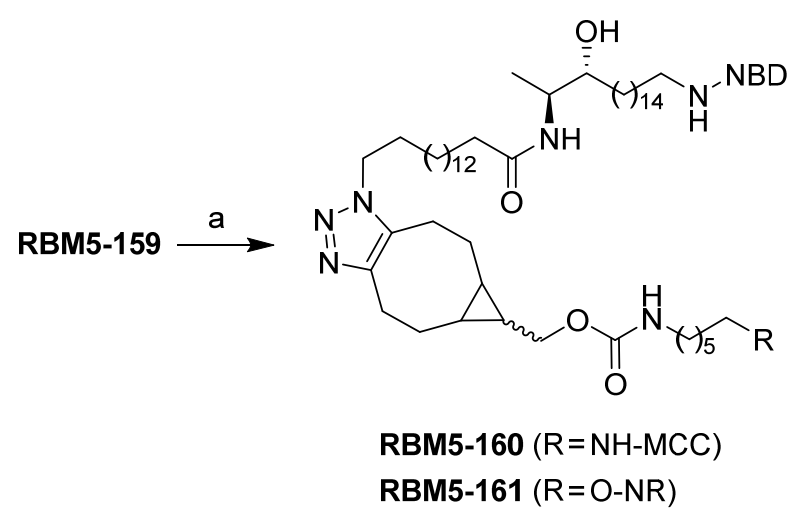

Scheme 12. Reagents and conditions: (a) RBM5-142 (for RBM5-160) or RBM5-143 (for RBM5-161), $\mathrm{CH}_{2} \mathrm{Cl}_{2}$, rt, overnight, 84-93\%.

\section{Fluorescence properties and FRET efficiency of the bichromophoric probes RBM5-160} and RBM5-161

After confirming the suitability of the selected fluorescent partners for their use in FRET experiments by calculation of the spectral overlap integral and Förster radius $\left(R_{0}\right)$ the normalised absorption and emission spectra of the compounds RBM5-160 and RBM5-161 in DMSO, EtOH and PBS buffer were determined (Figure 2). As expected, the absorption spectra of these compounds presented two bands owing to the presence of the two fluorescent labels. Compound RBM5-160 present two maxima at around $350 \mathrm{~nm}$ (MCC moiety) and $470 \mathrm{~nm}$ (NBD moiety). For compound RBM5-161, the maxima were located around $485 \mathrm{~nm}$ (NBD moiety) and $550 \mathrm{~nm}$ (NR moiety).

The fluorescence intensity was strongly affected by the solvent, the highest fluorescence intensities being recorded in EtOH for both compounds. However, their emission in PBS buffer was significantly reduced as a result of their low aqueous solubility. The position and shape of the spectra in both compounds were slightly modified in the different solvents, due to solvatochromic effects. Furthermore, there were also considerable deviations in the absorption spectra of compounds RBM5-160 and RBM5-161, when compared with the spectra of the related monochromophoric compounds, probably due to the intramolecular attractive interactions between the two fluorophores in each compound. ${ }^{42}$. 

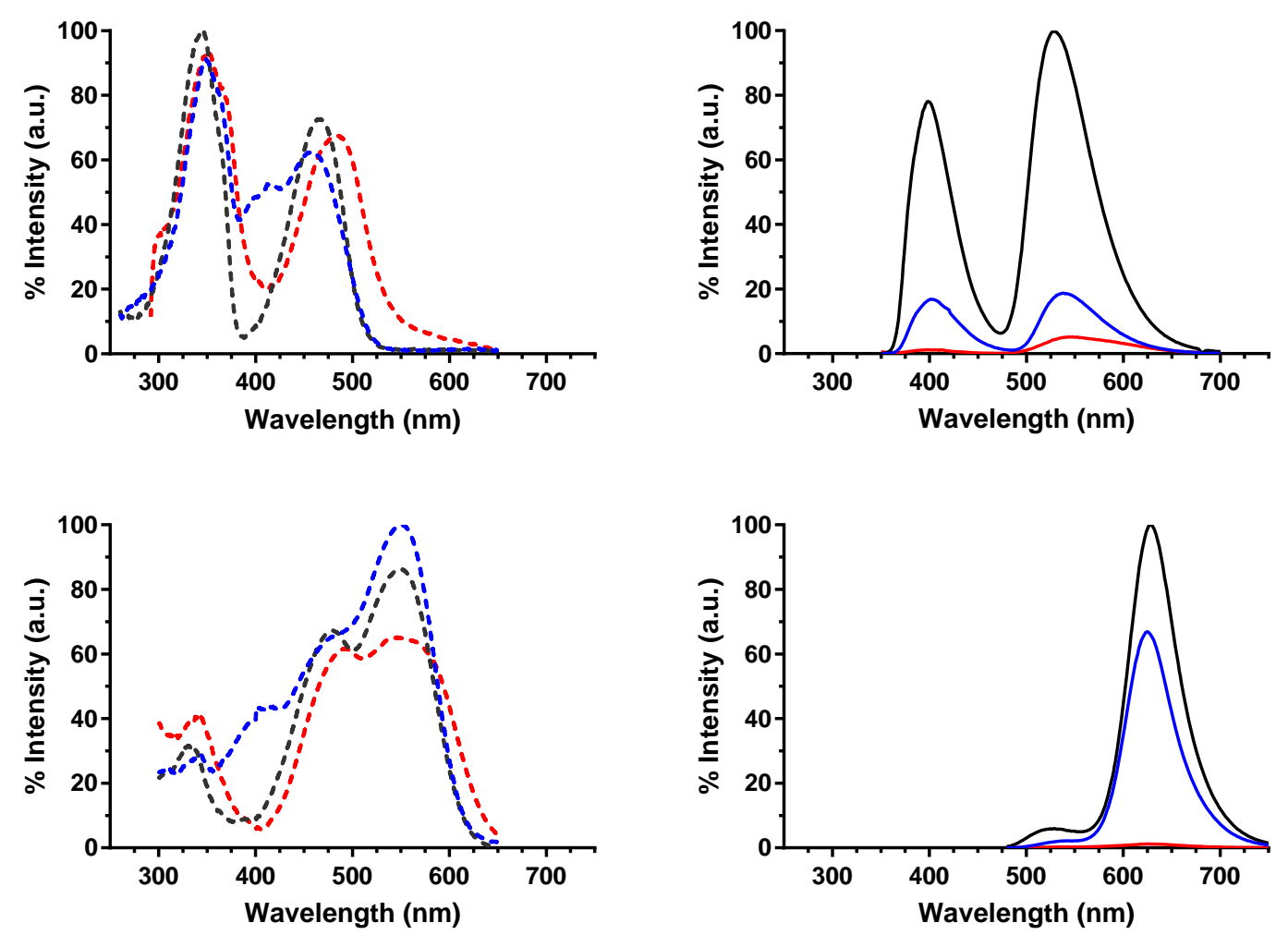

Figure 2. Normalised absorption (left panels) and emission (right panels) spectra for the bichromophoric compounds RBM5-160 (top) and RBM5-161 (bottom) at $5 \mu \mathrm{M}$ in DMSO (blue), EtOH (black) and PBS (red). Excitation at $340 \mathrm{~nm}$ (MCC) and $455 \mathrm{~nm}$ (NBD), respectively. The absorption and emission spectra of RBM5-160 in DMSO and PBS were normalized to those of the same compound in EtOH. The absorption spectra of RBM5-161 in EtOH and PBS were normalized to those in DMSO. The emission spectra of RBM5-161 in DMSO and PBS were normalized to those in EtOH.

The intramolecular FRET efficiencies of compounds RBM5-160 and RBM5-161 were estimated in DMSO and EtOH based on the loss of donor fluorescence in the presence of the acceptor. To this end, we compared the integrated fluorescence intensities $(I)$, within the donorspecific wavelength interval, of the donor-alone (D) compounds (RBM5-142 and RBM5-154) to those of the related donor+acceptor (DA) compounds (RBM5-160 and RBM5-161, respectively). The pair RBM5-142 / RBM5-160 was studied at one sole excitation wavelength (340 nm), whereas the pair RBM5-154 / RBM5-161 was studied at two different excitation wavelengths (455 $\mathrm{nm}$ and $470 \mathrm{~nm}$ ). The donor-specific emission wavelength intervals used for the former pair were $[365,495]$ in DMSO and $[360,490]$ in EtOH, whereas those used for the latter pair were $[490,670]$ in DMSO and $[480,660]$ in EtOH. A deconvolution process to correct for the overlapping of the emission bands of the donor and the acceptor components of RBM5160 and RBM5-161 was required prior to their use for the calculation of the FRET efficiency 
(see Supporting). As expected from the $R_{0}$ values, the calculated FRET efficiency of the $\mathrm{NBD} / \mathrm{NR}$ pair $\left(E_{\mathrm{NBD} / \mathrm{NR}}=0.88-0.96\right)$ was higher than that of the $\mathrm{MCC} / \mathrm{NBD}$ pair $\left(E_{\mathrm{MCC} / \mathrm{NBD}}=\right.$ 0.56-0.88). For both fluorophore pairs, the FRET process was more efficient in EtOH than in DMSO and, in the case of the NBD/NR pair, the two studied excitation wavelengths gave the same $E$ value (Table 1).

Table 1. Study of the intramolecular FRET process of the bichromophoric compounds RBM5-160 and RBM5-161. ${ }^{\text {a }}$ FRET efficiencies $(E)$ were calculated from the decrease of the donor emission; ${ }^{\mathrm{b}}$ Donor emission bleed-through is expressed as a percentage over the total integrated fluorescence intensity observed within the acceptor-specific emission wavelength interval. ${ }^{c}$ Acceptor emission bleed-through is expressed as a percentage over the total integrated fluorescence intensity observed within the acceptorspecific emission wavelength interval. The values outside and inside the parentheses were calculated from the "ratio A" and "ratio B" coefficients, respectively.

\begin{tabular}{llllll}
\hline Compound & Solvent & $\boldsymbol{\lambda}_{\boldsymbol{e x}}(\mathbf{n m})$ & $\boldsymbol{E}^{\mathbf{a}}$ & $\mathbf{D E B}^{\mathbf{b}}(\mathbf{\%})$ & $\mathbf{A E B}^{\mathbf{c}}(\mathbf{\%})$ \\
\hline \multirow{2}{*}{ RBM5-160 } & DMSO & 340 & 0.56 & 0.73 & $44.17(44.01)$ \\
\cline { 2 - 6 } & EtOH & 340 & 0.86 & 0.65 & $28.42(28.41)$ \\
& & 470 & 0.90 & 1.74 & $46.14(46.36)$ \\
\cline { 3 - 6 } RBM5-161 & & 455 & 0.88 & 1.92 & $39.01(39.03)$ \\
& EMSO & 470 & 0.96 & 1.73 & $36.28(36.33)$ \\
& & 455 & 0.96 & 1.93 & $24.44(24.48)$ \\
\end{tabular}

\section{Biomimetic SPAAC reaction between RBM5-159 and the fluorescent $B C N$ reagents}

The SPAAC reaction between the azide-tagged doxdhCer RBM5-159 and the two BCN-tagged fluorescent dyes RBM5-142 and RBM5-143 (Scheme 12) was studied under similar dilution conditions to those applicable in the CerS assay. The first assays were carried out in DMSO at different reaction times and reagent ratios. The reaction progress was monitored by analyzing the changes in the fluorescence emission of the mixture upon irradiation at $\lambda \mathrm{ex}=455$ (MCC excitation). In general terms, for RBM5-160 (donor: MCC, acceptor: NBD). the fluorescence emission at $\lambda \mathrm{em}=535$ (NBD emission) at single concentrations of RBM5-159 (5 and $20 \mu \mathrm{M})$ and increasing concentrations of the BCN-MCC reagent RBM5-142 (from 5 to $50 \mu \mathrm{M}$ ) was 
always lower than that of a standard of RBM5-160 at 5 and $20 \mu \mathrm{M}$ (results not shown). However, a similar experiment using the BCN-NR reagent RBM5-143 (from 5 to $50 \mu \mathrm{M}$ ) led to fluorescence intensities at $\lambda \mathrm{em}=625$ (NR emission) comparable to those of a standard of RBM5-161 using a 2.5 to 4 fold excess of the BCN reagent RBM5-143 (Figure 3).

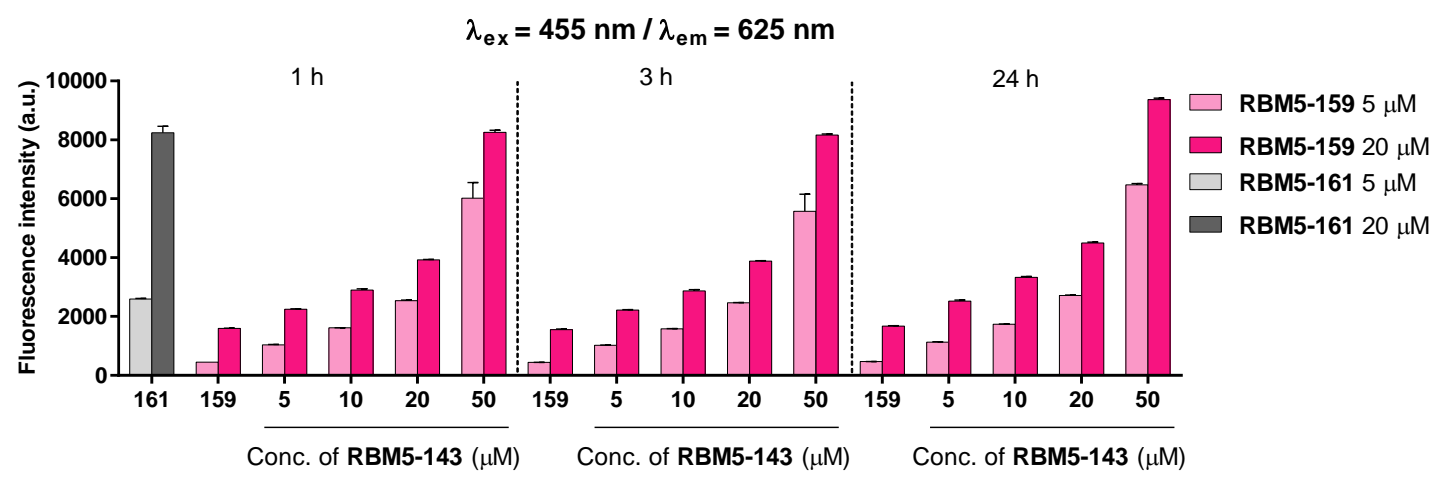

Figure 3. Bar diagram representing the changes in fluorescence emission at $625 \mathrm{~nm}$ (bottom), resulting from the excitation at $455 \mathrm{~nm}$, of mixtures containing different ratios of compounds RBM5-159 and RBM5-143 in DMSO at various reaction times. Compound RBM5-159 was used as the negative control, equivalent to $0 \%$ conversion, whereas compound RBM5-161 was used as the positive control, equivalent to $100 \%$ conversion. The results correspond to the mean \pm standard deviation of at least two independent experiments with triplicates.

Experiments in $\mathrm{MeOH}, \mathrm{EtOH}$ and sodium acetate buffer (NaOAc $250 \mathrm{mM}, \mathrm{NaCl} 200 \mathrm{mM}, 0.1$ $\%$ Triton X-100) also shown a remarkable enhancement of the emission at $625 \mathrm{~nm}\left(\lambda_{\mathrm{exc}}=455\right.$ $\mathrm{nm}$ ) in comparison with RBM5-159, together with an attenuation of the fluorescence emission at $535 \mathrm{~nm}\left(\lambda_{\mathrm{exc}}=455 \mathrm{~nm}\right)$. These results are in agreement with the formation of the desired cycloadduct RBM5-161, although a strong background emission for RBM5-143, as a result of the excitation cross-talk, was also evident (Figure 4). 

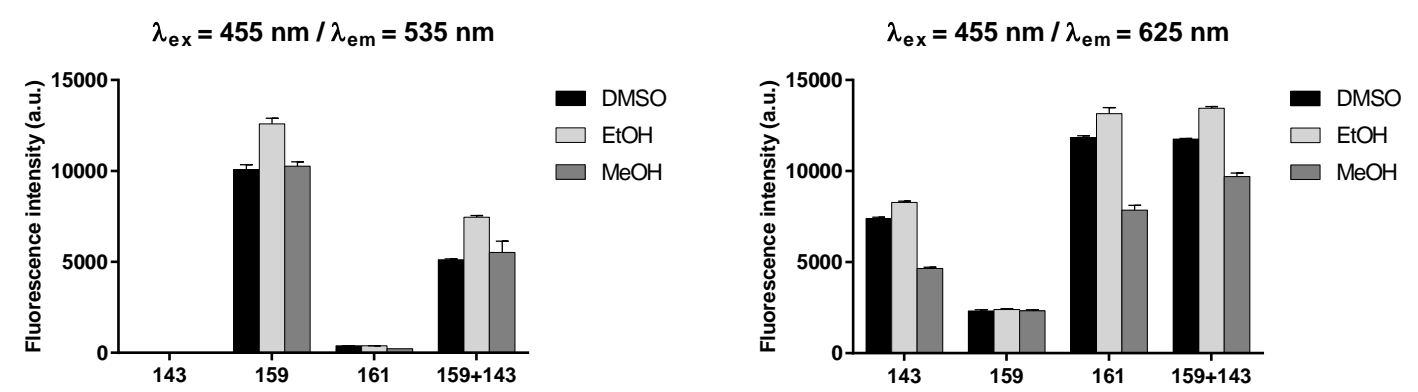

Figure 4. Bar diagram representing the fluorescence emission at $535 \mathrm{~nm}$ (left) and $625 \mathrm{~nm}$ (right), resulting from the excitation at $455 \mathrm{~nm}$, of a mixture containing the compounds RBM5$159(25 \mu \mathrm{M})$ and RBM5-143 $(50 \mu \mathrm{M})$ after $1 \mathrm{~h}$ reaction at $37^{\circ} \mathrm{C}$ in DMSO (black), EtOH (light grey) and $\mathrm{MeOH}$ (dark grey). The corresponding starting materials (RBM5-159 and RBM5143 at $25 \mu \mathrm{M})$ were used as the negative controls ( $0 \%$ conversion), whereas the appropriate cycloadduct (RBM5-161 at $25 \mu \mathrm{M}$ ) was used as the positive control (100\% conversion). The results correspond to the mean \pm standard deviation of at least two independent experiments with triplicates.

\section{CerS catalyzed acylation of RBM5-155 with $\omega$-azidopalmitic acid RBM5-065 in cells}

The suitability of probes RBM5-155 and the $\omega \mathrm{N}_{3}$ PA RBM5-065 as CerS substrates was evaluated by examining the extent of their metabolic conversion into the $N$-acylated doxdhCer RBM5-159. Initial experiments were carried out in A549 and MEF cells. Even though the total amount of doxdhCers, arising from acylation of RBM5-155 with endogenous fatty acids, was very similar in the two cell lines $\left(\sim 120-130\right.$ pmol equiv / $10^{6}$ cells $)$, the profile of the different doxdhCer species differed considerably. In A549 cells, there was a high proportion of C18N 3 and the elongated $\mathrm{C}_{2} 0 \mathrm{~N}_{3}$ doxdhCer species (by the action of the endogenous elongases ${ }^{43}$ ), whereas the non-elongated doxdhCer RBM5-159 accounted for less than a third of the total doxdhCers ( $28 \%$ ). Conversely, in MEF cells, the non-elongated RBM5-159 was the most abundant metabolite ( $85 \%$ of the total doxdhCers), whereas the formation of elongated species was minimal. These results show that the elongation process is unpredictable and highly dependent on the cell line. Attempts to reduce or avoid the acyl chain elongation by using the fatty acid biosynthesis inhibitors TOFA or cerulenin were fruitless. ${ }^{44-46}$ For practical purposes, overexpression of the CerS under study may improve the the signal-to-noise ratio of the assay. As a proof of concept, human embryonic kidney cells (HEK293T) were transfected with the human CerS5 gene using the cationic polymer polyethylenimine (PEI) ${ }^{47}$ and were subsequently incubated with the doxdhSo probe RBM5-155 and the $\omega$-azidopalmitic acid. UPLC-TOF 
analysis of the lipid extracts showed the higher proportion of C16-doxdhCer species in the transfected cells, in agreement with the expected preference of the CerS5 isoform for the C16 fatty acids. ${ }^{48}$ (Figure 5)
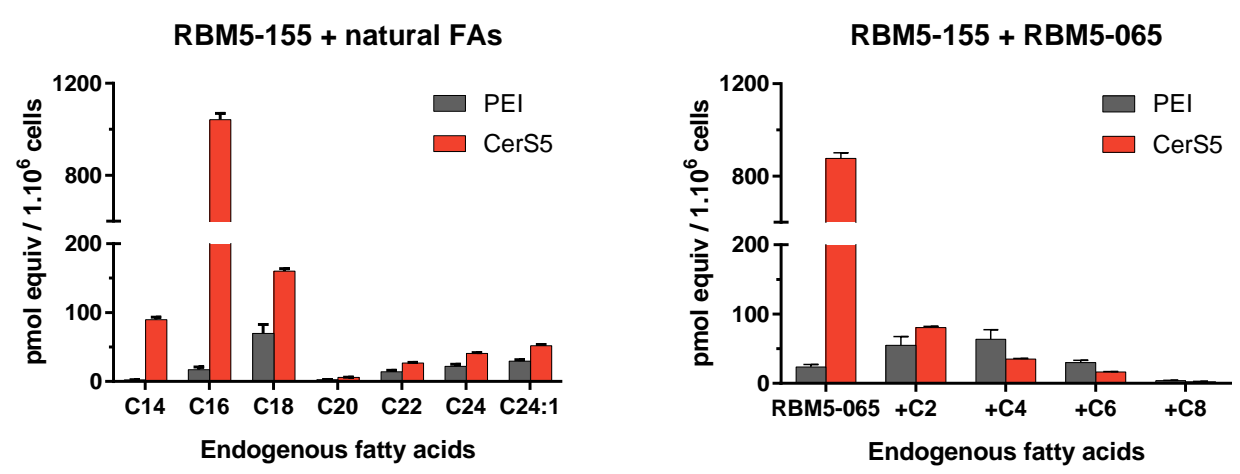

Figure 5. $N$-acylation of the doxdhSo probe RBM5-155 with the endogenous natural fatty acids or the $\omega$-azido fatty acid RBM5-065. HEK293T cells transfected with the plasmid containing human CerS5 (bars in orange) or simply treated with the transfection reagent PEI (bars in grey) were incubated for 90 min with RBM5-155 $(5 \mu \mathrm{M})$ in the absence (left) or the presence (right) of the $\omega_{\mathrm{N}} \mathrm{PA}$ RBM5-065 $(0.5 \mathrm{mM})$ complexed in 0.5\% acid-free BSA. After lipid extraction, the different doxdhCer species were quantified by UPLC-TOF. Left: Amount of doxdhCers containing endogenous natural fatty acids; Right: Amount of doxdhCers containing the administered RBM5-065 and the corresponding elongated fatty acids. The results correspond to the mean \pm standard deviation of at least two independent experiments with triplicates

\section{Conclusions}

In summary, the NBD probe RBM5-155 and the modified fatty acid $\omega_{\mathrm{N}} \mathrm{PA}$ RBM5-065 are suitable CerS substrates in different cell lines. Despite the degree of incorporation and elongation of the fatty acid is strongly dependent on the particular cell line, studies carried out with the model doxdhCer RBM5-159 indicated its suitability as a SPAAC reaction partner with the BCN modified Nile Red fluorophore RBM5-143 to render the bichromophoric doxdhCer RBM5-160, exhibiting a high FRET efficiency in the solvent systems used. These results represent a promising starting point for the development of a FRET-based CerS activity assay, which should complement those currently available for this interesting enzyme. Efforts along this line are underway in our lab and will be reported in due course. 


\section{Experimental}

\section{Chemistry}

All chemicals were purchased from commercial sources and used as received unless otherwise noted. Dry solvents (THF, DMF and $\mathrm{CH}_{2} \mathrm{Cl}_{2}$ ), obtained from a PureSolv dispenser and subsequently degassed with inert gas, were used in most reactions. Synthesis grade (Hexane, EtOAc, $\mathrm{Et}_{2} \mathrm{O}$ and $\left.\mathrm{CH}_{2} \mathrm{Cl}_{2}\right)$ or $\mathrm{HPLC}$-grade $(\mathrm{MeOH})$ solvents were used for extractions and purifications. Progression of the reactions was controlled by thin layer chromatography (TLC), using ALUGRAM ${ }^{\circledR}$ SIL G/UV254 (Macherey-Nagel) silica gel pre-coated aluminum sheets (Layer: $0.2 \mathrm{~mm}$, silica gel 60). Compounds were detected by using UV light ( $\lambda=254 \mathrm{~nm}$ ) and a stain solution of phosphomolibdic acid (5.7\% in EtOH). Usual work up refers to washing of the combined organic layers with brine $(2 \times 25 \mathrm{~mL})$, drying over anhydrous $\mathrm{MgSO}_{4}$ and concentration to dryness. Compounds were purified by flash column chromatography, using silica gel (Chromatogel $60 \AA, 35-75 \mu \mathrm{m})$ as stationary phase. Mobile phases and gradients are specified in each case. ${ }^{1} \mathrm{H}$ and ${ }^{13} \mathrm{C}$ Nuclear Magnetic Resonance spectra were recorded on a Varian - Mercury $400\left({ }^{1} \mathrm{H}\right.$ NMR at $400 \mathrm{MHz}$ and ${ }^{13} \mathrm{C}$ NMR at $\left.100.6 \mathrm{MHz}\right)$ spectrometer using $\mathrm{CDCl}_{3}$ or $\mathrm{CD}_{3} \mathrm{OD}$ as solvent. Chemical shifts of deuterated solvents were used as internal standards. Chemical shifts are given in parts per million (ppm) and coupling constants $(J)$ in Hertz (Hz). Splitting patterns have been described as singlet (s), broad singlet (br s), doublet (d), triplet (t), quartet (q), quintuplet (p), multiplet (m), apparent (app) or combinations of these descriptive names. Fourier transform infrared spectra were recorded on a FTIR Avatar 360 spectrophotometer. Samples were recorded neat using an attenuated total reflectance (ATR) accessory, or as thin films on $\mathrm{NaCl}$ plates (specified in each case in the following section). IR frequencies are reported in wave number $\left(\mathrm{cm}^{-1}\right)$. Specific optical rotations were recorded on a digital Perkin-Elmer 34 polarimeter at $25^{\circ} \mathrm{C}$ in a $1 \mathrm{dm}, 1 \mathrm{~mL}$ cell, using a sodium light lamp $(\lambda=589 \mathrm{~nm})$. Specific optical rotation values $\left([\alpha]_{\mathrm{D}}\right)$ are expressed in $\mathrm{deg}^{-1} \cdot \mathrm{cm}^{3} \cdot \mathrm{g}^{-1}$, and concentrations (c) are reported in $\mathrm{g} / 100 \mathrm{~mL}$ of solvent. High-resolution mass spectra were recorded Waters Aquity UPLC system connected to a Waters LCT Premier Orthogonal Accelerated Time of Flight Mass Spectrometer (Waters,Milford, MA, USA) operated in positive electrospray ionisation mode. Samples were analyzed by FIA (Flow Injection Analysis), using ACN/water (70:30) as mobile phase. Samples were analyzed using a $10 \mu \mathrm{L}$ volume injection. $\mathrm{M} / \mathrm{z}$ ratios are reported as values in atomic mass units. 
Absorption spectra were recorded on a Jasco V-730 UV-Vis spectrophotometer using a spectral bandwidth of $1 \mathrm{~nm}$, a response time of $0.24 \mathrm{sec}$, a data interval of $1 \mathrm{~nm}$ (except for quinine sulphate and compound RBM5-142, in which case the data interval was of $0.2 \mathrm{~nm}$ ) and a scan rate of $200 \mathrm{~nm} / \mathrm{min}$. Measurements were carried under inert atmosphere (continuous flow of nitrogen gas) at a constant temperature of $20^{\circ} \mathrm{C}$. The temperature was maintained with a MultiTemp III Thermostatic Circulator from Pharmacia Biotech. Fluorescence emission spectra were recorded on a Photon Technology International (PTI) QuantaMaster fluorometer at room temperature. The excitation and emission monochromators were set at $0.5 \mathrm{~mm}$, giving a spectral bandwidth of $2 \mathrm{~nm}$ (except for fluorescein and compounds RBM5-155 and RBM5-159, in which case the monochromators were set at $0.35 \mathrm{~mm}$, giving a spectral bandwidth of $1.4 \mathrm{~nm}$ ). The data interval was $1 \mathrm{~nm}$ and the integration time was $1 \mathrm{sec}$. All measurements were carried using a Hellma $1.5 \mathrm{~mL}$ PTFE-stoppered fluorescence quartz cuvette (4 clear windows) with a $1 \mathrm{~cm}$ path length.

\section{General procedures}

\section{General procedure 1: Acid-catalysed formation of methyl esters}

A solution of the selected carboxylic acid $(5 \mathrm{mmol})$ in $\mathrm{MeOH}(10 \mathrm{~mL})$ was treated with a catalytic amount of concentrated $\mathrm{H}_{2} \mathrm{SO}_{4}$ at $\mathrm{rt}$ and the mixture was then refluxed for $4 \mathrm{~h}$. The reaction was quenched by the addition of a few drops of saturated aqueous $\mathrm{NaHCO}_{3}$ and the volatiles were removed under reduced pressure. The residue was taken up in water $(50 \mathrm{~mL})$, extracted with EtOAc $(3 \times 50 \mathrm{~mL})$, and the combined extracts were washed with brine $(2 \times 25$ $\mathrm{mL}$ ), dried over $\mathrm{MgSO}_{4}$, filtered, and concentrated in vacuo. The crude mixture was purified by flash chromatography on a silica column to yield the corresponding methyl ester.

\section{General procedure 2: Base-catalysed hydrolysis of esters}

$\mathrm{LiOH}$ ( 3 equiv) was added in one portion to a stirred solution of the appropriate ester $(0.8 \mathrm{mmol})$ in $\mathrm{THF}-\mathrm{H}_{2} \mathrm{O}(3: 1)(80 \mathrm{~mL})$ at $0{ }^{\circ} \mathrm{C}$. After stirring at the same temperature for $2 \mathrm{~h}$, the reaction mixture was acidified with $1 \mathrm{M}$ aqueous $\mathrm{HCl}$ until $\mathrm{pH} 2$ and extracted with EtOAc $(3 \times 20 \mathrm{~mL})$. The combined organic extracts were dried over anhydrous $\mathrm{MgSO}_{4}$, filtered and concentrated under vacuum. The crude mixture was purified by flash column chromatography to give the corresponding carboxylic acids. 


\section{General procedure 3: Base-promoted dehydrohalogenation of terminal haloalkanes}

To a freshly prepared $1 \mathrm{M}$ solution of $\mathrm{KO} t \mathrm{Bu}$ (5 equiv) in dry THF $(25 \mathrm{~mL})$ was added a solution of the appropriate alkyl halide $(5 \mathrm{mmol})$ in dry THF $(5 \mathrm{~mL})$, and the resulting suspension was stirred at $\mathrm{rt}$ under argon atmosphere. After $4 \mathrm{~h}$, the reaction was quenched by the slow addition of $1 \mathrm{M}$ aqueous $\mathrm{HCl}(30 \mathrm{~mL})$ at $0{ }^{\circ} \mathrm{C}$, and the mixture was extracted with $\mathrm{Et}_{2} \mathrm{O}(3 \times 25 \mathrm{~mL})$. The combined organic layers were washed with brine $(2 \times 20 \mathrm{~mL})$, dried over $\mathrm{MgSO}_{4}$, and concentrated to give a crude, which was purified as indicated for each compound.

\section{General procedure 4: EDC/HOBt coupling for amide-bond formation (EIG290)}

$\mathrm{EDC} \cdot \mathrm{HCl}$ (1.6 equiv) and $\mathrm{HOBt}$ (1.3 equiv) were sequentially added to an ice-cooled solution of the corresponding carboxylic acid (1.1 equiv) in anhydrous $\mathrm{CH}_{2} \mathrm{Cl}_{2}(25 \mathrm{~mL})$, and the resulting mixture was vigorously stirred at $\mathrm{rt}$ under argon atmosphere. After $15 \mathrm{~min}$, the previous mixture was added dropwise to a solution of the selected amine $(5 \mathrm{mmol})$ and TEA ( 5 equiv) in anhydrous $\mathrm{CH}_{2} \mathrm{Cl}_{2}(25 \mathrm{~mL})$, and the reaction was stirred at $\mathrm{rt}$ for $2 \mathrm{~h}$. The mixture was next diluted with $\mathrm{CH}_{2} \mathrm{Cl}_{2}(50 \mathrm{~mL})$ and washed with brine $(2 \times 25 \mathrm{~mL})$. The organic layer was dried over $\mathrm{MgSO}_{4}$, filtered, and the volatiles were removed under reduced pressure. Purification of the crude mixture by flash column chromatography afforded the corresponding amide.

\section{Synthesis of the probes}

\section{a) Synthesis of NBD probes RBM5-155 and RBM5-159}

\section{5-Bromopentadec-1-ene (RBM5-149)}

A stirred solution of RBM5-148 ${ }^{49}$ (2.77 g, $\left.12.23 \mathrm{mmol}\right), \mathrm{PPh}_{3}(3.53 \mathrm{~g}, 13.46 \mathrm{mmol})$ in anhydrous $\mathrm{CH}_{2} \mathrm{Cl}_{2}(100 \mathrm{~mL})$ was cooled to $0{ }^{\circ} \mathrm{C}$, and NBS $(2.61 \mathrm{~g}, 14.68 \mathrm{mmol})$ was added in small portions over $10 \mathrm{~min}$. The resultant dark yellow solution was allowed to warm to $\mathrm{rt}$ and stirred for $1 \mathrm{~h}$, after which the solvent was removed by vacuum evaporation. The residue was then diluted with water $(50 \mathrm{~mL})$, extracted with hexanes $(3 \times 50 \mathrm{~mL})$ and worked-up as usual to give a crude, which was purified by flash chromatography on silica gel (isocratic $100 \%$ hexanes) to afford RBM5-149 as a colorless oil, (2.62 g, $74 \%)$

${ }^{1} \mathrm{H}$ NMR (400 MHz, $\left.\mathrm{CDCl}_{3}\right) \delta 5.81$ (ddt, $J=16.9,10.2,6.7 \mathrm{~Hz}, 1 \mathrm{H}$ ), 4.99 (dq, $J=17.1,1.9 \mathrm{~Hz}$, 1H), 4.93 (ddt, $J=10.2,2.4,1.4 \mathrm{~Hz}, 1 \mathrm{H}), 3.41$ (t, $J=6.9 \mathrm{~Hz}, 2 \mathrm{H}), 2.08-2.00$ (m, 2H), 1.85 $(\mathrm{dt}, J=14.5,7.0 \mathrm{~Hz}, 2 \mathrm{H}), 1.46-1.33(\mathrm{~m}, 3 \mathrm{H}), 1.32-1.25(\mathrm{~m}, 16 \mathrm{H})$. 
${ }^{13} \mathrm{C}$ NMR (101 MHz, $\left.\mathrm{CDCl}_{3}\right) \delta 139.4,114.2,34.2,34.0,33.0,29.8,29.8,29.7,29.7,29.6,29.3$, $29.1,28.9,28.3$.

(2'S,3'R,4'EZ) tert-butyl (18-Bromo-3-hydroxyoctadec-4-en-2-yl)carbamate (RBM5-150)

To a stirred solution of RBM5-084 ${ }^{19,50}$ (480 mg, $2.38 \mathrm{mmol}$ ) and olefin RBM5-149 (1.59 g, $5.49 \mathrm{mmol})$ in degassed $\mathrm{CH}_{2} \mathrm{Cl}_{2}(20 \mathrm{~mL}), 2^{\text {nd }}$ generation Grubbs' catalyst (101 mg, $\left.0.12 \mathrm{mmol}\right)$ was added in one portion at rt. The resulting mixture was refluxed in the dark for $2 \mathrm{~h}$, cooled to rt and concentrated in vacuo to afford a crude, which was purified by flash chromatography on silica gel (from 0 to $5 \%$ MTBE in $\mathrm{CH}_{2} \mathrm{Cl}_{2}$ ). Compound RBM5-150 was obtained as an inseparable mixture of $E / Z$ isomers (colourless thick oil, $485 \mathrm{mg}, 44 \%$ ).

${ }^{1} \mathrm{H}$ NMR (400 MHz, $\left.\mathrm{CDCl}_{3}\right)(E$ isomer) $\delta 5.71(\mathrm{dt}, J=14.6,6.7 \mathrm{~Hz}, 1 \mathrm{H}), 5.42(\mathrm{dt}, J=15.0,7.5$ $\mathrm{Hz}, 1 \mathrm{H}), 4.76($ br s, $1 \mathrm{H}), 4.11(\mathrm{dd}, J=6.4,3.0 \mathrm{~Hz}, 1 \mathrm{H}), 3.73-3.58(\mathrm{~m}, 1 \mathrm{H}), 3.40(\mathrm{t}, J=6.9 \mathrm{~Hz}$, 2H), $2.09-1.96(\mathrm{~m}, 2 \mathrm{H}), 1.85(\mathrm{dt}, J=14.5,6.9 \mathrm{~Hz}, 2 \mathrm{H}), 1.44(\mathrm{~s}, 9 \mathrm{H}), 1.43-1.23(\mathrm{~m}, 20 \mathrm{H})$, $1.07(\mathrm{~d}, J=6.9 \mathrm{~Hz}, 3 \mathrm{H})$.

${ }^{13} \mathrm{C}$ NMR (101 MHz, $\mathrm{CDCl}_{3}$ ) (mixture of $E / Z$ isomers) $\delta 156.1,155.7,134.2,133.5,129.4$, $128.7,125.6,124.9,79.4,79.2,75.4,73.5,51.0,50.0,37.3,33.9,33.4,32.8,32.6,32.3,29.6$, $29.5,29.5,29.4,29.2,28.7,28.4,28.1,15.2,14.3$.

\section{(2'S,3'R) tert-butyl (18-Bromo-3-hydroxyoctadecan-2-yl)carbamate (RBM5-151)}

A solution of RBM5-150 (450 mg, $0.97 \mathrm{mmol}$ ) in degassed MeOH (45 mL) was hydrogenated at $1 \mathrm{~atm}$ and $\mathrm{rt}$ in the presence of $\mathrm{Rh} / \mathrm{Al}_{2} \mathrm{O}_{3}(60 \mathrm{mg}, 15 \% \mathrm{w} / \mathrm{w})$. After stirring for $3 \mathrm{~h}$, the catalyst was removed by filtration through a Celite ${ }^{\circledR}$ pad, and the solid was rinsed with $\mathrm{MeOH}(3 \times 10$ $\mathrm{mL}$ ). The combined filtrates were concentrated in vacuo, and the residue was subjected to flash chromatography on silica gel (from 0 to $1 \% \mathrm{MeOH}$ in $\mathrm{CH}_{2} \mathrm{Cl}_{2}$ ).to yield RBM5-151 as a white solid (395 mg, $87 \%)$.

$[\alpha]^{20}{ }_{\mathrm{D}}=-3.65\left(c 1, \mathrm{CHCl}_{3}\right)$.

${ }^{1} \mathrm{H}$ NMR $\left(400 \mathrm{MHz}, \mathrm{CDCl}_{3}\right) \delta 4.74($ br s, $1 \mathrm{H}), 3.70-3.67(\mathrm{~m}, 1 \mathrm{H}), 3.64(\mathrm{td}, J=8.0,7.2,2.7$ $\mathrm{Hz}, 1 \mathrm{H}), 3.41$ (t, $J=6.9 \mathrm{~Hz}, 2 \mathrm{H}), 1.85$ (dt, $J=14.5,7.0 \mathrm{~Hz}, 2 \mathrm{H}), 1.71$ (br s, 1H), 1.44 (s, 9H), $1.43-1.35(\mathrm{~m}, 4 \mathrm{H}), 1.34-1.23(\mathrm{~m}, 22 \mathrm{H}), 1.08(\mathrm{~d}, J=6.8 \mathrm{~Hz}, 3 \mathrm{H})$. 
${ }^{13} \mathrm{C}$ NMR $\left(101 \mathrm{MHz}, \mathrm{CDCl}_{3}\right) \delta 156.0,79.6,74.6,50.8,34.2,33.6,33.0,29.8,29.7,29.6,28.9$, $28.6,28.3,26.2,14.5$.

HRMS calcd. for $\mathrm{C}_{23} \mathrm{H}_{47} \mathrm{BrNO}_{3}\left([\mathrm{M}+\mathrm{H}]^{+}\right)$: 464.2734, 466.2713, found: 464.2729, 466.2718.

\section{(2'S,3'R) tert-butyl (18-Azido-3-hydroxyoctadecan-2-yl)carbamate (RBM5-152)}

To a stirred solution of RBM5-151 (395 mg, $0.85 \mathrm{mmol}$ ) in anhydrous DMF (8 mL) was added $\mathrm{NaN}_{3}$ (166 mg, $2.55 \mathrm{mmol}$ ). The mixture was heated to $80{ }^{\circ} \mathrm{C}$ and stirred for $3 \mathrm{~h}$ under Ar. Water $(20 \mathrm{~mL})$ was next added, and the mixture was extracted with $\mathrm{Et}_{2} \mathrm{O}(3 \times 20 \mathrm{~mL})$. Usual workup afforded a crude, which was purified by flash chromatography (from 0 to $1 \% \mathrm{MeOH}$ in $\mathrm{CH}_{2} \mathrm{Cl}_{2}$ ) to give RBM5-152 (off-white wax, $346 \mathrm{mg}$, $95 \%$ ).

$[\alpha]^{20} \mathrm{D}=-4.13\left(c 1, \mathrm{CHCl}_{3}\right)$.

${ }^{1} \mathrm{H}$ NMR (400 MHz, $\left.\mathrm{CDCl}_{3}\right) \delta 4.75(\mathrm{~s}, 1 \mathrm{H}), 3.71-3.67(\mathrm{~m}, 1 \mathrm{H}), 3.66-3.61(\mathrm{~m}, 1 \mathrm{H}), 3.25(\mathrm{t}$, $J=7.0 \mathrm{~Hz}, 2 \mathrm{H}), 1.75$ (br s, 1H), $1.66-1.54(\mathrm{~m}, 2 \mathrm{H}), 1.44$ (s, 9H), $1.40-1.35$ (m, 4H), $1.34-$ $1.23(\mathrm{~m}, 22 \mathrm{H}), 1.07(\mathrm{~d}, J=6.8 \mathrm{~Hz}, 3 \mathrm{H})$.

${ }^{13} \mathrm{C}$ NMR $\left(101 \mathrm{MHz}, \mathrm{CDCl}_{3}\right) \delta 156.0,79.6,74.6,51.6,50.7,33.6,29.8,29.8,29.7,29.7,29.7$, $29.7,29.6,29.3,29.0,28.5,26.8,26.2,14.4$.

HRMS calcd. for $\mathrm{C}_{23} \mathrm{H}_{47} \mathrm{~N}_{4} \mathrm{O}_{3}\left([\mathrm{M}+\mathrm{H}]^{+}\right)$: 427.3643, found: 427.3636 .

\section{(2'S,3'R) tert-butyl (18-Amino-3-hydroxyoctadecan-2-yl)carbamate (RBM5-153)}

To a solution of RBM5-152 (300 mg, $0.70 \mathrm{mmol}$ ) in degassed MeOH (16 mL) containing Pd$\mathrm{C}(60 \mathrm{mg}, 20 \% \mathrm{w} / \mathrm{w})$ neat TES $(1.1 \mathrm{~mL}, 7.03 \mathrm{mmol})$ was added dropwise, and the resultant suspension was stirred at rt under an Ar-filled balloon. After stirring for $1 \mathrm{~h}$, the reaction mixture was filtered through a pad of Celite ${ }^{\circledR}$ and the solid was rinsed with $\mathrm{MeOH}(3 \times 5 \mathrm{~mL})$. The combined filtrates were concentrated in vacuo and the residue was triturated with hexanes $(4 \mathrm{x}$ $2 \mathrm{~mL}$ ) to give the desired amine hydrochloride, without the need of further purification.

${ }^{1} \mathrm{H}$ NMR (400 MHz, CD $\left.3 \mathrm{OD}\right) \delta 3.53-3.47(\mathrm{~m}, 1 \mathrm{H}), 3.47-3.41(\mathrm{~m}, 1 \mathrm{H}), 2.67(\mathrm{t}, J=7.1 \mathrm{~Hz}$, 2H), $1.53-1.46(\mathrm{~m}, 4 \mathrm{H}), 1.44(\mathrm{~s}, 9 \mathrm{H}), 1.30(\mathrm{~s}, 24 \mathrm{H}), 1.08(\mathrm{~d}, J=6.6 \mathrm{~Hz}, 3 \mathrm{H})$.

${ }^{13} \mathrm{C}$ NMR (101 MHz, CD $\left.3 \mathrm{OD}\right) \delta 157.8,79.9,75.3,51.8,42.3,34.8,33.0,30.8,30.7,30.6,28.8$, $28.0,27.1,15.5$. 
HRMS calcd. for $\mathrm{C}_{23} \mathrm{H}_{49} \mathrm{~N}_{2} \mathrm{O}_{3}\left([\mathrm{M}+\mathrm{H}]^{+}\right): 401.3738$, found: 401.3742 .

$\left(2^{\prime} S, 3 ' R\right) \quad$ tert-butyl $\quad[3-H y d r o x y-18-[(7-n i t r o b e n z o[c][1,2,5]$ oxadiazol-4yl)amino]octadecan-2-yl]carbamate (RBM5-154)

To a stirred solution of 4-chloro-7-nitrobenzo[c][1,2,5]oxadiazole (NBD-Cl) (132 mg, 0.66 $\mathrm{mmol})$ in $\mathrm{MeOH}(15 \mathrm{~mL})$ containing DIPEA $(522 \mu \mathrm{L}, 3.00 \mathrm{mmol})$ at $0{ }^{\circ} \mathrm{C}$ was added dropwise a solution of RBM5-153 (240 mg, $0.60 \mathrm{mmol})$ in $\mathrm{MeOH}(10 \mathrm{~mL})$. After the addition was complete, the mixture was allowed to warm to rt and stirred overnight. Then, the volatiles were removed under reduced pressure and the residue was directly subjected to flash chromatography on silica gel (from 0 to $1 \% \mathrm{MeOH}$ in $\mathrm{CH}_{2} \mathrm{Cl}_{2}$ ) to provide RBM5-154 as a shiny orange wax (278 mg, $82 \%)$.

${ }^{1} \mathrm{H}$ NMR $\left(400 \mathrm{MHz}, \mathrm{CDCl}_{3}\right) \delta 8.49(\mathrm{~d}, J=8.6 \mathrm{~Hz}, 1 \mathrm{H}), 6.31(\mathrm{br} \mathrm{s}, 1 \mathrm{H}), 6.17(\mathrm{~d}, J=8.7 \mathrm{~Hz}$, 1H), 4.75 (br s, 1H), $3.73-3.66(\mathrm{~m}, 1 \mathrm{H}), 3.66-3.62(\mathrm{~m}, 1 \mathrm{H}), 3.49$ (ap q, $J=6.7 \mathrm{~Hz}, 2 \mathrm{H}), 1.86$ (br s, 1H), $1.81(\mathrm{dt}, J=14.9,7.4 \mathrm{~Hz}, 2 \mathrm{H}), 1.53-1.44(\mathrm{~m}, 2 \mathrm{H}), 1.44(\mathrm{~s}, 9 \mathrm{H}), 1.41-1.35$ (m, 4H), $1.33-1.23(\mathrm{~m}, 20 \mathrm{H}), 1.07(\mathrm{~d}, J=6.8 \mathrm{~Hz}, 3 \mathrm{H})$.

${ }^{13} \mathrm{C} \mathrm{NMR}\left(101 \mathrm{MHz}, \mathrm{CDCl}_{3}\right) \delta 156.0,144.3,144.2,144.0,136.7,123.7,98.6,79.6,74.6,50.8$, $44.2,33.6,29.8,29.7,29.7,29.7,29.6,29.6,29.5,29.3,28.6,28.5,27.0,26.1,14.5$.

HRMS calcd. for $\mathrm{C}_{29} \mathrm{H}_{50} \mathrm{~N}_{5} \mathrm{O}_{6}\left([\mathrm{M}+\mathrm{H}]^{+}\right)$: 564.3756, found: 564.3761 .

(2S,3R) 2-Amino-18-[(7-nitrobenzo[c][1,2,5]oxadiazol-4-yl)amino]octadecan-3-ol hydrochloride (RBM5-155)

An ice-cooled solution of RBM5-154 (85 mg, $0.15 \mathrm{mmol})$ in $\mathrm{MeOH}(10 \mathrm{~mL})$ was treated with neat $\mathrm{AcCl}(54 \mu \mathrm{L}, 0.75 \mathrm{mmol})$ and the resulting mixture was allowed to warm to $\mathrm{rt}$ and stirred overnight in the dark. Then, the solvent was evaporated in vacuo and the residue was purified by flash chromatography on silica gel (from 0 to $20 \% \mathrm{MeOH}$ in $\mathrm{CH}_{2} \mathrm{Cl}_{2}$ ) to afford $\mathbf{R B M 5 - 1 5 5}$ as a shiny orange wax ( $65 \mathrm{mg}, 86 \%)$.

${ }^{1} \mathrm{H}$ NMR (400 MHz, CD $\left.3 \mathrm{OD}\right) \delta 8.52(\mathrm{~d}, J=8.7 \mathrm{~Hz}, 1 \mathrm{H}), 6.35(\mathrm{~d}, J=8.9 \mathrm{~Hz}, 1 \mathrm{H}), 3.75-3.65$ (m, 1H), $3.53($ br s, 2H), $3.31-3.22(\mathrm{~m}, 1 \mathrm{H}), 1.77$ (app p, $J=7.4 \mathrm{~Hz}, 2 \mathrm{H}), 1.55-1.37(\mathrm{~m}, 8 \mathrm{H})$, $1.36-1.25(\mathrm{~m}, 18 \mathrm{H}), 1.22(\mathrm{~d}, J=6.8 \mathrm{~Hz}, 3 \mathrm{H})$. 
${ }^{13} \mathrm{C}$ NMR (101 MHz, CD $\left.3 \mathrm{OD}\right) \delta 146.7,145.8,145.5,138.6,122.7,99.6,71.7,52.6,44.8,34.0$, $30.7,30.6,30.3,29.2,28.0,27.0,12.1$.

HRMS calcd. for $\mathrm{C}_{24} \mathrm{H}_{42} \mathrm{~N}_{5} \mathrm{O}_{4}\left([\mathrm{M}+\mathrm{H}]^{+}\right)$: 464.3231, found: 464.3228 .

\section{$(2 ' S, 3 ' R)-16-A z i d o-N-[3-h y d r o x y-18-[(7-n i t r o b e n z o[c][1,2,5]$ oxadiazol-4-}

\section{yl)amino]octadecan-2-yl]hexadecanamide (RBM5-159)}

$\mathrm{EDC} \cdot \mathrm{HCl}(12 \mathrm{mg}, 64 \mu \mathrm{mol})$ and $\mathrm{HOBt}(7 \mathrm{mg}, 52 \mu \mathrm{mol})$ were sequentially added to an ice-cooled solution of $\omega$-azidopalmitic $\operatorname{acid}^{30}(13 \mathrm{mg}, 44 \mu \mathrm{mol})$ in anhydrous $\mathrm{CH}_{2} \mathrm{Cl}_{2}(6 \mathrm{~mL})$. The resulting mixture was vigorously stirred at $\mathrm{rt}$ under Ar for $15 \mathrm{~min}$, and next added dropwise to a solution of RBM5-155 (20 mg, $40 \mu \mathrm{mol})$ and $\mathrm{Et}_{3} \mathrm{~N}(89 \mu \mathrm{L}, 0.20 \mathrm{mmol})$ in anhydrous $\mathrm{CH}_{2} \mathrm{Cl}_{2}(6 \mathrm{~mL})$, and the reaction was stirred at $\mathrm{rt}$ for additional $2 \mathrm{~h}$. The mixture was next diluted with $\mathrm{CH}_{2} \mathrm{Cl}_{2}(50 \mathrm{~mL})$, washed with brine $(2 \times 25 \mathrm{~mL})$ and worked-up as usual to afford a crude, which was flash chromatographed (from 0 to $14 \% \mathrm{EtOAc}$ in $\mathrm{CH}_{2} \mathrm{Cl}_{2}$ ) to afford RBM5-159 as a shiny orange solid (22 $\mathrm{mg}, 74 \%)$.

${ }^{1} \mathrm{H}$ NMR $\left(400 \mathrm{MHz}, \mathrm{CDCl}_{3}\right) \delta 8.48(\mathrm{~d}, J=8.6 \mathrm{~Hz}, 1 \mathrm{H}), 6.49(\mathrm{br} \mathrm{s}, 1 \mathrm{H}), 6.17(\mathrm{~d}, J=8.7 \mathrm{~Hz}$, $1 \mathrm{H}), 5.81(\mathrm{~d}, J=7.9 \mathrm{~Hz}, 1 \mathrm{H}), 4.05-3.96(\mathrm{~m}, 1 \mathrm{H}), 3.66-3.59(\mathrm{~m}, 1 \mathrm{H}), 3.53-3.45(\mathrm{~m}, 2 \mathrm{H})$, $3.24(\mathrm{t}, J=7.0 \mathrm{~Hz}, 2 \mathrm{H}), 2.51($ br s, $1 \mathrm{H}), 2.17$ (t, $J=7.6 \mathrm{~Hz}, 2 \mathrm{H}), 1.80($ app p, $J=7.4 \mathrm{~Hz}, 2 \mathrm{H})$, $1.69-1.53(\mathrm{~m}, 4 \mathrm{H}), 1.49-1.20(\mathrm{~m}, 48 \mathrm{H}), 1.09(\mathrm{~d}, J=6.8 \mathrm{~Hz}, 3 \mathrm{H})$.

${ }^{13} \mathrm{C} \mathrm{NMR}\left(101 \mathrm{MHz}, \mathrm{CDCl}_{3}\right) \delta 173.4,144.4,144.1,144.1,136.7,123.9,98.6,74.5,51.6,49.6$, 44.2, 37.0, 33.7, 29.7, 29.7, 29.5, 29.5, 29.4, 29.3, 29.0, 28.6, 27.1, 26.8, 26.1, 25.9, 14.3.

\section{b) Synthesis of the fatty acids}

\section{b1) Diene fatty acids}

The synthesis of diene fatty acid RBM5-029 is representative

\section{Methyl 7-bromoheptanoate (RBM5-027)}

Compound RBM5-027 (light yellow oil, 3.13 g, 98 \%) was obtained from 7-bromoheptanoic acid $(3.00 \mathrm{~g}, 14.35 \mathrm{mmol})$ in refluxing $\mathrm{MeOH}(30 \mathrm{~mL})$ containing a catalytic amount of $\mathrm{H}_{2} \mathrm{SO}_{4}$ $(30 \mu \mathrm{L})$ according to the general procedure 1 . Upon ${ }^{1} \mathrm{H}-\mathrm{NMR}$ analysis, the crude of the reaction was deemed sufficiently pure for the next step.

${ }^{1} \mathrm{H}$ NMR (400 MHz, $\left.\mathrm{CDCl}_{3}\right) \delta 3.66(\mathrm{~d}, J=1.7 \mathrm{~Hz}, 3 \mathrm{H}), 3.39(\mathrm{t}, J=6.8 \mathrm{~Hz}, 2 \mathrm{H}), 2.31(\mathrm{t}, J=7.5$ $\mathrm{Hz}, 2 \mathrm{H}), 1.90-1.79(\mathrm{~m}, 2 \mathrm{H}), 1.69-1.58(\mathrm{~m}, 2 \mathrm{H}), 1.50-1.40(\mathrm{~m}, 2 \mathrm{H}), 1.39-1.28(\mathrm{~m}, 2 \mathrm{H})$. 
${ }^{13} \mathrm{C}$ NMR (101 MHz, $\left.\mathrm{CDCl}_{3}\right) \delta 174.2,51.6,34.0,33.9,32.7,28.4,27.9,24.8$.

HRMS calcd. for $\mathrm{C}_{8} \mathrm{H}_{16} \mathrm{BrO}_{2}\left([\mathrm{M}+\mathrm{H}]^{+}\right)$: 223.0328, 225.0308, found: 223.0331, 225.0315 .

Methyl 7-(((2E,4E)-hexa-2,4-dien-1-yl)oxy)heptanoate (RBM5-028a) and (2E,4E)-hexa2,4-dien-1-yl 7-(((2E,4E)-hexa-2,4-dien-1-yl)oxy)heptanoate (RBM5-028b)

Sorbyl alcohol (660 mg, $6.72 \mathrm{mmol})$ was added carefully at $0{ }^{\circ} \mathrm{C}$ to a stirred suspension of $\mathrm{NaH}$ $(60 \%(\mathrm{w} / \mathrm{w})$ in mineral oil, $296 \mathrm{mg}, 7.40 \mathrm{mmol})$ in dry DMF $(18 \mathrm{~mL})$ and the mixture was allowed to warm to $\mathrm{rt}$ and stirred for additional $30 \mathrm{~min}$. Then, the temperature was lowered again to $0{ }^{\circ} \mathrm{C}$ followed by the sequential addition of $\mathrm{NaI}(101 \mathrm{mg}, 0.67 \mathrm{mmol})$ and RBM5-027 $(1.50 \mathrm{~g}, 6.72 \mathrm{mmol})$. After stirring at $\mathrm{rt}$ for $4 \mathrm{~h}$, the reaction was quenched by the dropwise addition of ice-cold water $(20 \mathrm{~mL})$. When the evolution of gas ceased, the mixture was extracted with $\mathrm{Et}_{2} \mathrm{O}(3 \times 50 \mathrm{~mL})$ and the combined organic extracts were washed with brine $(3 \times 20 \mathrm{~mL})$, dried over anhydrous $\mathrm{MgSO}_{4}$, filtered and evaporated under vacuum. The residue was subjected to flash column chromatography (from 0 to $4 \%$ EtOAc in hexanes) to afford an inseparable mixture of esters RBM5-028a and RBM5-028b (colourless oil, $704 \mathrm{mg}$ ). First-eluting fractions (RBM5-028b) and last-eluting fractions (RBM5-028a) were independently collected to give a sample of the pure products, from which the following data were acquired.

\section{RBM5-028a:}

${ }^{1} \mathrm{H}$ NMR $\left(400 \mathrm{MHz}, \mathrm{CDCl}_{3}\right) \delta 6.23-6.15(\mathrm{~m}, 1 \mathrm{H}), 6.10-6.01(\mathrm{~m}, 1 \mathrm{H}), 5.75-5.65(\mathrm{~m}, 1 \mathrm{H})$, $5.64-5.57(\mathrm{~m}, 1 \mathrm{H}), 3.96(\mathrm{~d}, J=6.4 \mathrm{~Hz}, 2 \mathrm{H}), 3.66(\mathrm{~s}, 3 \mathrm{H}), 3.40(\mathrm{t}, J=6.6 \mathrm{~Hz}, 2 \mathrm{H}), 2.31(\mathrm{t}, J=$ $7.5 \mathrm{~Hz}, 2 \mathrm{H}), 1.75(\mathrm{~d}, J=6.2 \mathrm{~Hz}, 3 \mathrm{H}), 1.69-1.61(\mathrm{~m}, 2 \mathrm{H}), 1.60-1.55(\mathrm{~m}, 2 \mathrm{H}), 1.43-1.34(\mathrm{~m}$, $2 \mathrm{H}), 1.28-1.20(\mathrm{~m}, 2 \mathrm{H})$.

\section{RBM5-028b:}

${ }^{1} \mathrm{H}$ NMR (400 MHz, $\left.\mathrm{CDCl}_{3}\right) \delta 6.28-6.12(\mathrm{~m}, 2 \mathrm{H}), 6.10-5.98(\mathrm{~m}, 2 \mathrm{H}), 5.79-5.67(\mathrm{~m}, 2 \mathrm{H})$, $5.66-5.56(\mathrm{~m}, 2 \mathrm{H}), 4.56(\mathrm{~d}, J=6.6 \mathrm{~Hz}, 2 \mathrm{H}), 3.95(\mathrm{~d}, J=6.3 \mathrm{~Hz}, 2 \mathrm{H}), 3.39(\mathrm{t}, J=6.5 \mathrm{~Hz}, 2 \mathrm{H})$, $2.30(\mathrm{t}, J=7.5 \mathrm{~Hz}, 2 \mathrm{H}), 1.78-1.71(\mathrm{~m}, 6 \mathrm{H}), 1.68-1.61(\mathrm{~m}, 2 \mathrm{H}), 1.60-1.54(\mathrm{~m}, 2 \mathrm{H}), 1.42-$ $1.33(\mathrm{~m}, 2 \mathrm{H}), 1.28-1.20(\mathrm{~m}, 2 \mathrm{H})$.

HRMS calcd. for $\mathrm{C}_{19} \mathrm{H}_{31} \mathrm{O}_{3}\left([\mathrm{M}+\mathrm{H}]^{+}\right)$: 307.2268, found: 307.2268 .

\section{7-(((2E,4E)-Hexa-2,4-dien-1-yl)oxy)heptanoic acid (RBM5-029)}

Compound RBM5-029 (white solid, $466 \mathrm{mg}, 22 \%$ over two steps) was obtained from the previous mixture of esters RBM5-028a and RBM5-028b (704 mg) and LiOH (175 mg, 7.30 
mmol) in THF- $\mathrm{H}_{2} \mathrm{O}(3: 1)(240 \mathrm{~mL})$ according to the general procedure 2 . The title compound was purified by flash column chromatography on silica gel (from 0 to $50 \%$ EtOAc in hexanes). ${ }^{1} \mathrm{H}$ NMR $\left(400 \mathrm{MHz}, \mathrm{CDCl}_{3}\right) \delta 6.18(\mathrm{dd}, J=15.1,10.4 \mathrm{~Hz}, 1 \mathrm{H}), 6.05(\mathrm{ddd}, J=14.8,10.4,1.8$ $\mathrm{Hz}, 1 \mathrm{H}), 5.70(\mathrm{dt}, J=14.8,6.9 \mathrm{~Hz}, 1 \mathrm{H}), 5.62(\mathrm{dt}, \mathrm{J}=15.1,6.2 \mathrm{~Hz}, 1 \mathrm{H}), 3.96(\mathrm{~d}, \mathrm{~J}=6.3 \mathrm{~Hz}$, $2 \mathrm{H}), 3.40(\mathrm{t}, J=6.6 \mathrm{~Hz}, 2 \mathrm{H}), 2.34(\mathrm{t}, J=7.5 \mathrm{~Hz}, 2 \mathrm{H}), 1.75(\mathrm{dd}, J=6.7,1.6 \mathrm{~Hz}, 3 \mathrm{H}), 1.68-$ $1.61(\mathrm{~m}, 2 \mathrm{H}), 1.60-1.53(\mathrm{~m}, 2 \mathrm{H}), 1.39-1.33(\mathrm{~m}, 4 \mathrm{H})$.

${ }^{13} \mathrm{C}$ NMR $\left(101 \mathrm{MHz} \mathrm{CDCl}_{3}\right) \delta 180.0,133.2,131.0,130.0,127.0,71.3,70.2,34.1,29.7,29.0$, 26.0, 24.7, 18.2.

HRMS calcd. for $\mathrm{C}_{13} \mathrm{H}_{21} \mathrm{O}_{3}\left([\mathrm{M}-\mathrm{H}]^{-}\right)$: 225.1496, found: 225.1476 .

\section{b2) Alkene fatty acid RBM5-097}

\section{Methyl 16-iodohexadecanoate (RBM5-098)}

NIS (2.54 g, $11.31 \mathrm{mmol})$ was added in small portions, over a period of $10 \mathrm{~min}$, to a stirred solution of RBM5-063 (2.70 g, $9.43 \mathrm{mmol})$ and $\mathrm{PPh}_{3}(2.72 \mathrm{~g}, 10.37 \mathrm{mmol})$ in anhydrous $\mathrm{CH}_{2} \mathrm{Cl}_{2}(20 \mathrm{~mL})$ at $0{ }^{\circ} \mathrm{C}$. After the addition was complete, the resultant dark brown solution was allowed to warm to rt. After stirring overnight, the solvent was evaporated in vacuo, and the residue was diluted with water $(50 \mathrm{~mL})$, extracted with hexanes $(3 \times 50 \mathrm{~mL})$, and the combined organic layers were washed with brine $(2 \times 25 \mathrm{~mL})$, dried over anhydrous $\mathrm{MgSO}_{4}$ and concentrated to dryness. Purification of the crude product by flash column chromatography (from 0 to $10 \%$ EtOAc in hexanes) yielded RBM5-098 (3.68 g, $98 \%$ ) as a pale-yellow wax. ${ }^{1} \mathrm{H}$ NMR (400 MHz, $\left.\mathrm{CDCl}_{3}\right) \delta 3.66(\mathrm{~s}, 3 \mathrm{H}), 3.18(\mathrm{t}, J=7.1 \mathrm{~Hz}, 2 \mathrm{H}), 2.29(\mathrm{t}, J=7.6 \mathrm{~Hz}, 2 \mathrm{H})$, $1.86-1.77(\mathrm{~m}, 2 \mathrm{H}), 1.66-1.56(\mathrm{~m}, 2 \mathrm{H}), 1.42-1.33(\mathrm{~m}, 2 \mathrm{H}), 1.33-1.22(\mathrm{~m}, 20 \mathrm{H})$.

${ }^{13} \mathrm{C} \mathrm{NMR}\left(101 \mathrm{MHz}, \mathrm{CDCl}_{3}\right) \delta 174.5,51.6,34.3,33.7,30.7,29.8,29.7,29.7,29.7,29.6,29.6$, 29.4, 29.3, 28.7, 25.1, 7.5.

HRMS calcd. for $\mathrm{C}_{17} \mathrm{H}_{34} \mathrm{IO}_{2}\left([\mathrm{M}+\mathrm{H}]^{+}\right)$: 397.1598 , found: 397.1605 .

\section{tert-Butyl 15-hexadecenoate (RBM5-099)}

Compound RBM5-099 (colourless oil, $1.23 \mathrm{~g}$, 79 \%) was obtained from RBM5-098 (2.00 g, $5.05 \mathrm{mmol})$, and $\mathrm{KO} t \mathrm{Bu}(2.83 \mathrm{~g}, 25.23 \mathrm{mmol})$ in anhydrous THF $(25 \mathrm{~mL})$ according to the general procedure 3 . The title compound was purified by flash chromatography on silica gel (from 0 to $1 \%$ MTBE in hexanes). 
${ }^{1} \mathrm{H}$ NMR $\left(400 \mathrm{MHz}, \mathrm{CDCl}_{3}\right) \delta 5.81$ (ddt, $\left.J=17.0,10.2,6.7 \mathrm{~Hz}, 1 \mathrm{H}\right), 4.99$ (ddt, $J=17.1,2.2$, $1.6 \mathrm{~Hz}, 1 \mathrm{H}), 4.92$ (ddt, $J=10.2,2.3,1.2 \mathrm{~Hz}, 1 \mathrm{H}), 2.20$ (t, $J=7.5 \mathrm{~Hz}, 2 \mathrm{H}), 2.08-2.00(\mathrm{~m}, 2 \mathrm{H})$, $1.62-1.52(\mathrm{~m}, 2 \mathrm{H}), 1.44(\mathrm{~s}, 9 \mathrm{H}), 1.41-1.33(\mathrm{~m}, 2 \mathrm{H}), 1.32-1.22(\mathrm{~m}, 18 \mathrm{H})$.

${ }^{13} \mathrm{C} \mathrm{NMR}\left(101 \mathrm{MHz}, \mathrm{CDCl}_{3}\right) \delta 173.3,139.3,114.0,79.8,35.6,33.8,29.6,29.6,29.5,29.5$, $29.3,29.1,29.1,28.9,28.1,25.1$.

\section{5-Hexadecenoic acid (RBM5-097)}

Neat TFA ( $5 \mathrm{~mL}$ ) was added dropwise to an ice-cooled solution of tert-butyl ester RBM5-099 (350 mg, $1.13 \mathrm{mmol})$ in dry $\mathrm{CH}_{2} \mathrm{Cl}_{2}(5 \mathrm{~mL})$. After stirring at $\mathrm{rt}$ for $2 \mathrm{~h}$, the reaction mixture was concentrated in vacuo to give a crude, which was subjected to flash column chromatography on silica gel (from 0 to $10 \%$ EtOAc in hexanes) to afford RBM5-097 (240 mg, $84 \%$ ) as a paleyellow wax.

${ }^{1} \mathrm{H} \mathrm{NMR}\left(400 \mathrm{MHz}, \mathrm{CDCl}_{3}\right) \delta 11.11$ (br s, 1H), 5.81 (ddt, $\left.J=16.9,10.2,6.7 \mathrm{~Hz}, 1 \mathrm{H}\right), 4.99$ (dd, $J=17.1,1.7 \mathrm{~Hz}, 1 \mathrm{H}), 4.95-4.90(\mathrm{~m}, 1 \mathrm{H}), 2.35(\mathrm{t}, J=7.5 \mathrm{~Hz}, 2 \mathrm{H}), 2.04$ (app q, $J=7.0 \mathrm{~Hz}$, 2H), 1.63 (app p, $J=7.5 \mathrm{~Hz}, 2 \mathrm{H}), 1.41-1.20$ (m, 20H).

${ }^{13} \mathrm{C}$ NMR $\left(101 \mathrm{MHz}, \mathrm{CDCl}_{3}\right) \delta 180.2,139.4,114.2,34.2,34.0,29.8,29.7,29.7,29.6,29.4$, $29.3,29.2,29.1,24.8$.

HRMS calcd. for $\mathrm{C}_{16} \mathrm{H}_{29} \mathrm{O}_{2}\left([\mathrm{M}-\mathrm{H}]^{-}\right)$: 253.2173, found: 253.2169 .

\section{b3) Azido fatty acids}

The synthesis of RBM5-065 is representative

\section{Methyl 16-hydroxyhexadecanoate (RBM5-063)}

Compound RBM5-063 (white solid, $980 \mathrm{mg}$, 93 \%) was obtained from 16-hydroxyhexadecanoic acid (1.00 g, $3.67 \mathrm{mmol})$ in refluxing $\mathrm{MeOH}(20 \mathrm{~mL})$ containing a catalytic amount of $\mathrm{H}_{2} \mathrm{SO}_{4}(20 \mu \mathrm{L})$ according to the general procedure 1. The title compound was purified by flash column chromatography on silica gel (from 0 to $20 \%$ EtOAc in hexanes). ${ }^{1} \mathrm{H}$ NMR (400 MHz, CDCl 3$) \delta 3.66(\mathrm{~s}, 3 \mathrm{H}), 3.64(\mathrm{t}, J=6.7 \mathrm{~Hz}, 2 \mathrm{H}), 2.30(\mathrm{t}, J=7.6 \mathrm{~Hz}, 2 \mathrm{H})$, $1.65-1.52(\mathrm{~m}, 4 \mathrm{H}), 1.38-1.22(\mathrm{~m}, 22 \mathrm{H})$.

${ }^{13} \mathrm{C} \mathrm{NMR}\left(101 \mathrm{MHz}, \mathrm{cdcl}_{3}\right) \delta 174.5,63.2,51.6,34.2,32.9,29.8,29.7,29.7,29.7,29.6,29.4$, $29.3,25.9,25.1$. 


\section{Methyl 16-azidohexadecanoate (RBM5-064)}

Method A: Compound RBM5-064 (white solid, $460 \mathrm{mg}$, 85 \%) was obtained from primary alcohol RBM5-063 (500 mg, $1.75 \mathrm{mmol}$ ), NBS (373 mg, 2.09 mmol), PPh 3 (504 mg, 1.92 mmol) and $\mathrm{NaN}_{3}(340 \mathrm{mg}, 5.24 \mathrm{mmol})$ in dry DMF $(18 \mathrm{~mL})$ according to the procedure described for compound RBM5-018. The title compound was purified by flash column chromatography on silica gel (from 0 to $14 \% \mathrm{Et}_{2} \mathrm{O}$ in hexanes).

Method B: DBU (339 $\mu \mathrm{L}, 2.27 \mathrm{mmol})$ and DPPA (489 $\mu \mathrm{L}, 2.27 \mathrm{mmol})$ were sequentially added to an ice-cooled solution of the primary alcohol RBM5-063 (500 mg, $1.75 \mathrm{mmol})$ in dry DMF $(3.5 \mathrm{~mL})$ and the resulting mixture was allowed to warm to rt. After stirring overnight, water $(10 \mathrm{~mL})$ was added and the mixture was extracted with $\mathrm{Et}_{2} \mathrm{O}(3 \times 25 \mathrm{~mL})$. The combined organic extracts were washed with brine $(3 \times 10 \mathrm{~mL})$, dried over anhydrous $\mathrm{MgSO}_{4}$, filtered and concentrated under reduced pressure. The residue was subjected to flash column chromatography on silica gel (from 0 to $14 \% \mathrm{Et}_{2} \mathrm{O}$ in hexanes) to afford RBM5-064 (440 mg, $81 \%)$ as a white solid.

${ }^{1} \mathrm{H}$ NMR (400 MHz, $\left.\mathrm{CDCl}_{3}\right) \delta 3.66(\mathrm{~s}, 3 \mathrm{H}), 3.25(\mathrm{t}, J=7.0 \mathrm{~Hz}, 2 \mathrm{H}), 2.30(\mathrm{t}, J=7.6 \mathrm{~Hz}, 2 \mathrm{H})$, $1.66-1.53(\mathrm{~m}, 4 \mathrm{H}), 1.40-1.22(\mathrm{~m}, 22 \mathrm{H})$.

${ }^{13} \mathrm{C}$ NMR (101 MHz, $\left.\mathrm{CDCl}_{3}\right) \delta 174.5,51.6,51.6,34.3,29.8,29.8,29.7,29.7,29.6,29.6,29.4$, $29.3,29.0,26.9,25.1$.

\section{6-Azidohexadecanoic acid (RBM5-065)}

Compound RBM5-065 (off-white solid, $335 \mathrm{mg}, 78$ \%) was obtained from methyl ester RBM5064 (450 mg, $1.44 \mathrm{mmol})$ and $\mathrm{LiOH}(104 \mathrm{mg}, 4.33 \mathrm{mmol})$ in $\mathrm{THF}-\mathrm{H}_{2} \mathrm{O}(3: 1)(160 \mathrm{~mL})$ according to the general procedure 2. The title compound was purified by flash column chromatography on silica gel (from 100:0:1 to 80:20:1 hexanes/Et $2 \mathrm{O} / \mathrm{AcOH}$ ).

${ }^{1} \mathrm{H}$ NMR (400 MHz, $\left.\mathrm{CDCl}_{3}\right) \delta 11.34$ (br s, $\left.J=0.3 \mathrm{~Hz}, 1 \mathrm{H}\right), 3.25$ (t, $\left.J=7.0 \mathrm{~Hz}, 2 \mathrm{H}\right), 2.34$ (t, $J$ $=7.5 \mathrm{~Hz}, 2 \mathrm{H}), 1.68-1.55(\mathrm{~m}, 4 \mathrm{H}), 1.40-1.22(\mathrm{~m}, 22 \mathrm{H})$.

${ }^{13} \mathrm{C} \mathrm{NMR}\left(101 \mathrm{MHz}, \mathrm{CDCl}_{3}\right) \delta 180.3,51.6,34.2,29.8,29.8,29.7,29.7,29.7,29.6,29.6,29.4$, 29.3, 29.2, 29.0, 26.9, 24.8 .

HRMS calcd. for $\mathrm{C}_{16} \mathrm{H}_{30} \mathrm{~N}_{3} \mathrm{O}_{2}\left([\mathrm{M}-\mathrm{H}]^{-}\right)$: 296.2344, found: 296.2337. 
c) Synthesis of the fluorescent reagents

\section{c1) Tetrazines}

The synthesis of RBM5-139 and RBM5-140 are representative

tert-butyl (6-(7-Methoxy-2-oxo-2H-chromene-3-carboxamido)hexyl)carbamate (RBM5135)

Compound RBM5-135 (white solid, $200 \mathrm{mg}, 57 \%$ ) was obtained from $N$-Boc-1,6hexanediamine $(187 \mu \mathrm{L}, 0.83 \mathrm{mmol}), 7$-methoxycoumarin-3-carboxylic acid (202 mg, 0.92 $\mathrm{mmol}), \mathrm{EDC} \cdot \mathrm{HCl}(255 \mathrm{mg}, 1.33 \mathrm{mmol})$, and $\mathrm{HOBt}(146 \mathrm{mg}, 1.08 \mathrm{mmol})$ in anhydrous $\mathrm{CH}_{2} \mathrm{Cl}_{2}$ (40 mL) containing $\mathrm{Et}_{3} \mathrm{~N}(580 \mu \mathrm{L}, 4.16 \mathrm{mmol})$ according to the general procedure 4 . Purification of the crude material by flash column chromatography on silica gel (from 0 to $5 \%$ $\mathrm{MeOH}$ in $\mathrm{CH}_{2} \mathrm{Cl}_{2}$ ) afforded the title compound.

${ }^{1} \mathrm{H}$ NMR $\left(400 \mathrm{MHz}, \mathrm{CDCl}_{3}\right) \delta 8.81(\mathrm{~s}, 1 \mathrm{H}), 8.74(\mathrm{br} \mathrm{s}, 1 \mathrm{H}), 7.56(\mathrm{~d}, J=8.6 \mathrm{~Hz}, 1 \mathrm{H}), 6.92(\mathrm{~d}, J$ $=8.2 \mathrm{~Hz}, 1 \mathrm{H}), 6.85(\mathrm{~s}, 1 \mathrm{H}), 4.55(\mathrm{br} \mathrm{s}, 1 \mathrm{H}), 3.90(\mathrm{~s}, 3 \mathrm{H}), 3.48-3.36(\mathrm{~m}, 2 \mathrm{H}), 3.09(\mathrm{~m}, 2 \mathrm{H})$, $1.66-1.56(\mathrm{~m}, 2 \mathrm{H}), 1.52-1.31(\mathrm{~m}, 15 \mathrm{H})$.

${ }^{13} \mathrm{C} \mathrm{NMR}\left(101 \mathrm{MHz}, \mathrm{CDCl}_{3}\right) \delta 164.9,162.1,162.0,156.7,156.1,148.3,131.0,115.0,114.1$, 112.6, 100.4, 79.1, 56.1, 40.6, 39.8, 30.1, 29.5, 28.5, 26.8, 26.5.

HRMS calcd. for $\mathrm{C}_{22} \mathrm{H}_{31} \mathrm{~N}_{2} \mathrm{O}_{6}\left([\mathrm{M}+\mathrm{H}]^{+}\right)$: 419.2177, found: 419.2181 .

tert-butyl (6-((9-(Diethylamino)-5-oxo-5H-benzo[a]phenoxazin-2-yl)oxy)hexyl)carbamate (RBM5-136)

Compound RBM5-136 (red solid, $500 \mathrm{mg}, 78$ \%) was obtained from RBM5-133 (500 mg, 1.20 $\mathrm{mmol}$ ), $\mathrm{K}_{2} \mathrm{CO}_{3}(397 \mathrm{mg}, 2.87 \mathrm{mmol}$ ) and RBM5-134 (369 mg, $1.32 \mathrm{mmol}$ ) in dry DMF (30 $\mathrm{mL}$ ) according to the methodology described for RBM5-120. The title compound was obtained after flash column chromatography of the crude material (isocratic 6:4 hexane/EtOAc).

${ }^{1} \mathrm{H}$ NMR (400 MHz, $\left.\mathrm{CDCl}_{3}\right) \delta 8.21(\mathrm{~d}, J=8.7 \mathrm{~Hz}, 1 \mathrm{H}), 8.04(\mathrm{~d}, J=2.6 \mathrm{~Hz}, 1 \mathrm{H}), 7.61(\mathrm{~d}, J=$ $9.1 \mathrm{~Hz}, 1 \mathrm{H}), 7.16(\mathrm{dd}, J=8.7,2.6 \mathrm{~Hz}, 1 \mathrm{H}), 6.66(\mathrm{dd}, J=9.1,2.7 \mathrm{~Hz}, 1 \mathrm{H}), 6.47(\mathrm{~d}, J=2.7 \mathrm{~Hz}$, 1H), 6.31 (s, 1H), 4.53 (br s, 1H), 4.17 (t, $J=6.4 \mathrm{~Hz}, 2 \mathrm{H}), 3.47$ (q, $J=7.1 \mathrm{~Hz}, 4 \mathrm{H}), 3.19-3.09$ $(\mathrm{m}, 2 \mathrm{H}), 1.91-1.82(\mathrm{~m}, 2 \mathrm{H}), 1.58-1.51(\mathrm{~m}, 4 \mathrm{H}), 1.44(\mathrm{~s}, 11 \mathrm{H}), 1.26(\mathrm{t}, J=7.1 \mathrm{~Hz}, 6 \mathrm{H})$.

${ }^{13} \mathrm{C}$ NMR $\left(101 \mathrm{MHz}, \mathrm{CDCl}_{3}\right) \delta 183.4,161.9,156.1,152.2,150.8,146.9,140.2,134.2,131.2$, $127.8,125.7,124.8,118.4,109.6,106.7,105.4,96.4,79.2,68.3,45.2,40.7,30.2,29.3,28.6$, $26.7,25.9,12.8$. 
HRMS calcd. for $\mathrm{C}_{31} \mathrm{H}_{40} \mathrm{~N}_{3} \mathrm{O}_{5}\left([\mathrm{M}+\mathrm{H}]^{+}\right)$: 534.2962, found: 534.2965.

\section{7-Methoxy-2-oxo- $N$-(6-(4-(6-(pyrimidin-2-yl)-1,2,4,5-tetrazin-3-yl)benzamido)hexyl)-2H- chromene-3-carboxamide (RBM5-139)}

Neat TFA (1.5 mL) was added dropwise to an ice-cooled solution of $N$-Boc protected amine RBM5-135 (100 mg, $0.24 \mathrm{mmol})$ in dry $\mathrm{CH}_{2} \mathrm{Cl}_{2}(3 \mathrm{~mL})$. After stirring in the dark at $\mathrm{rt}$ for $2 \mathrm{~h}$, the reaction mixture was concentrated to dryness to afford the corresponding crude amine trifluoroacetate $(75 \mathrm{mg})$. This crude was taken up in $\mathrm{CH}_{2} \mathrm{Cl}_{2} / \mathrm{Et}_{3} \mathrm{~N}(10: 1,11 \mathrm{~mL})$, followed by the addition of $N$-hydroxysuccinimide ester RBM5-138 (90 mg, $0.24 \mathrm{mmol}$ ). After stirring overnight at $\mathrm{rt}$ in the dark, the reaction mixture was evaporated in vacuo and the residue was subjected to flash column chromatography (from 0 to $5 \% \mathrm{MeOH}$ in $\mathrm{CH}_{2} \mathrm{Cl}_{2}$ ) to give RBM5139 (35 $\mathrm{mg}, 25 \%$ ) as a pale pink solid.

${ }^{1} \mathrm{H}$ NMR $\left(400 \mathrm{MHz}, \mathrm{CDCl}_{3}\right) \delta 9.15(\mathrm{~d}, J=4.8 \mathrm{~Hz}, 2 \mathrm{H}), 8.82(\mathrm{~d}, J=8.0 \mathrm{~Hz}, 2 \mathrm{H}), 8.79(\mathrm{~s}, 1 \mathrm{H})$, $8.08(\mathrm{~d}, J=8.3 \mathrm{~Hz}, 2 \mathrm{H}), 7.61(\mathrm{~s}, 1 \mathrm{H}), 7.55(\mathrm{~d}, J=8.9 \mathrm{~Hz}, 1 \mathrm{H}), 7.52(\mathrm{~s}, 1 \mathrm{H}), 6.92$ (d, $J=9.3$ Hz, 1H), 6.86 (s, 1H), 6.59 (br s, 1H), 3.91 (s, 3H), $3.57-3.46$ (m, 4H), $1.70-1.28$ (m, 8H). HRMS calcd. for $\mathrm{C}_{30} \mathrm{H}_{29} \mathrm{~N}_{8} \mathrm{O}_{5}\left([\mathrm{M}+\mathrm{H}]^{+}\right)$: 581.2255 , found: 581.2253 .

\section{$N$-(6-((9-(Diethylamino)-5-oxo-5H-benzo[a]phenoxazin-2-yl)oxy)hexyl)-4-(6-(pyrimidin-}

\section{2-yl)-1,2,4,5-tetrazin-3-yl)benzamide (RBM5-140)}

Neat TFA $(1.5 \mathrm{~mL})$ was added dropwise to an ice-cooled solution of $N$-Boc protected amine RBM5-136 (100 mg, $0.19 \mathrm{mmol})$ in dry $\mathrm{CH}_{2} \mathrm{Cl}_{2}(3 \mathrm{~mL})$ After stirring at $\mathrm{rt}$ for $2 \mathrm{~h}$ in the dark, the reaction mixture was concentrated to dryness to afford the corresponding crude amine trifluoroacetate $(82 \mathrm{mg})$. This crude was taken up in $\mathrm{CH}_{2} \mathrm{Cl}_{2} / \mathrm{Et}_{3} \mathrm{~N}(10: 1,11 \mathrm{~mL})$, followed by the addition of $N$-hydroxysuccinimide ester RBM5-138 (70 mg, $0.19 \mathrm{mmol}$ ). After stirring overnight at $\mathrm{rt}$ in the dark, the reaction mixture was evaporated in vacuo and the residue was

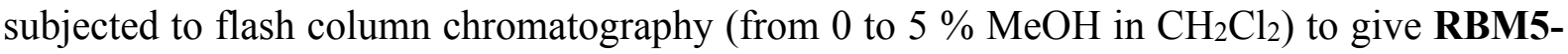
140 (125 mg, $99 \%)$ as a dark red solid.

${ }^{1} \mathrm{H}$ NMR $\left(400 \mathrm{MHz}, \mathrm{CDCl}_{3}\right) \delta 9.15(\mathrm{~d}, J=4.8 \mathrm{~Hz}, 2 \mathrm{H}), 8.78(\mathrm{t}, J=4.9 \mathrm{~Hz}, 2 \mathrm{H}), 8.20(\mathrm{~d}, J=$ $8.7 \mathrm{~Hz}, 1 \mathrm{H}), 8.03(\mathrm{~d}, J=2.6 \mathrm{~Hz}, 1 \mathrm{H}), 8.01(\mathrm{~d}, J=8.4 \mathrm{~Hz}, 2 \mathrm{H}), 7.61(\mathrm{t}, J=9.6 \mathrm{~Hz}, 1 \mathrm{H}), 7.59$ $(\mathrm{d}, J=9.5 \mathrm{~Hz}, 2 \mathrm{H}), 7.15(\mathrm{dd}, J=8.7,2.6 \mathrm{~Hz}, 1 \mathrm{H}), 6.66(\mathrm{dd}, J=9.1,2.7 \mathrm{~Hz}, 1 \mathrm{H}), 6.45(\mathrm{~d}, J=$ $2.7 \mathrm{~Hz}, 1 \mathrm{H}), 6.37$ (t, $J=5.7 \mathrm{~Hz}, 1 \mathrm{H}), 6.32(\mathrm{~s}, 1 \mathrm{H}), 4.19$ (t, $J=6.3 \mathrm{~Hz}, 2 \mathrm{H}), 3.56$ (q, $J=6.8 \mathrm{~Hz}$, 
2H), $3.46(\mathrm{q}, J=7.1,6.5 \mathrm{~Hz}, 4 \mathrm{H}), 1.95-1.86(\mathrm{~m}, 2 \mathrm{H}), 1.79-1.49(\mathrm{~m}, 6 \mathrm{H}), 1.26(\mathrm{t}, J=7.1 \mathrm{~Hz}$, $6 \mathrm{H})$.

${ }^{13} \mathrm{C}$ NMR (101 MHz, $\left.\mathrm{CDCl}_{3}\right) \delta 183.7,166.8,162.0,158.6,152.3,151.0,139.9,131.3,129.1$, 128.0, 128.0, 125.0, 122.8, 118.4, 111.8, 109.8, 106.8, 105.2, 96.4, 68.3, 45.2, 40.4, 29.7, 29.2, 25.9, 25.6, 12.8 (some of the carbon atoms with non bonded hydrogens were undetected due to the scarce solubility of the sample).

HRMS calcd. for $\mathrm{C}_{39} \mathrm{H}_{38} \mathrm{~N}_{9} \mathrm{O}_{4}\left([\mathrm{M}+\mathrm{H}]^{+}\right)$: 696.3041, found: 696.3043 .

\section{c2) Bicyclononynes}

[(1R,8S,9s)-Bicyclo[6.1.0]non-4-yn-9-yl]methyl

[6-(7-methoxy-2-oxo-2H-chromene-3carboxamido)hexyl]carbamate (RBM5-142)

To an ice-cooled solution of $\mathrm{N}$-Boc protected amine RBM5-135 (93 $\mathrm{mg}, 0.22 \mathrm{mmol}$ ) in dry $\mathrm{CH}_{2} \mathrm{Cl}_{2}(6 \mathrm{~mL})$ was added dropwise neat TFA $(1.5 \mathrm{~mL})$. After stirring at $\mathrm{rt}$ for $2 \mathrm{~h}$ in the dark, the reaction mixture was concentrated to dryness to afford the corresponding crude amine trifluoroacetate $(71 \mathrm{mg})$. This crude was taken up in $\mathrm{CH}_{2} \mathrm{Cl}_{2}(10 \mathrm{~mL})$, followed by the sequential addition of $\mathrm{Et}_{3} \mathrm{~N}(108 \mu \mathrm{L}, 0.78 \mathrm{mmol})$ and $p$-nitrophenol activated carbonate ester RBM5-141 ${ }^{41}$ (70 $\mathrm{mg}, 0.22 \mathrm{mmol}$ ). After stirring overnight at $\mathrm{rt}$ in the dark, the reaction mixture was evaporated in vacuo and the residue was flash chromatographed (from 0 to $20 \%$ EtOAc in $\left.\mathrm{CH}_{2} \mathrm{Cl}_{2}\right)$ to give the desired carbamate RBM5-142 (98 mg, $89 \%$ ) as an off-white solid.

${ }^{1} \mathrm{H}$ NMR (400 MHz, $\left.\mathrm{CDCl}_{3}\right) \delta 8.83(\mathrm{~s}, 1 \mathrm{H}), 8.76(\mathrm{br} \mathrm{s}, 1 \mathrm{H}), 7.58(\mathrm{~d}, J=8.7 \mathrm{~Hz}, 1 \mathrm{H}), 6.93$ (dd, $J=8.7,2.4 \mathrm{~Hz}, 1 \mathrm{H}), 6.86(\mathrm{~d}, J=2.4 \mathrm{~Hz}, 1 \mathrm{H}), 4.69$ (br s, 1H), 4.13 (d, $J=8.1 \mathrm{~Hz}, 2 \mathrm{H}), 3.91$ (s, $3 \mathrm{H}), 3.44(\mathrm{td}, J=7.1,5.8 \mathrm{~Hz}, 2 \mathrm{H}), 3.20-3.12(\mathrm{~m}, 2 \mathrm{H}), 2.34-2.15(\mathrm{~m}, 6 \mathrm{H}), 1.67-1.24(\mathrm{~m}$, $11 \mathrm{H}), 0.99-0.86(\mathrm{~m}, 2 \mathrm{H})$.

${ }^{13} \mathrm{C}$ NMR $\left(101 \mathrm{MHz}, \mathrm{CDCl}_{3}\right) \delta 164.9,162.1,162.1,156.9,156.8,148.3,131.0,115.0,114.1$, 112.6, 100.4, 99.0, 62.7, 56.2, 41.0, 39.7, 30.0, 29.5, 29.2, 26.7, 26.5, 21.6, 20.2, 18.0.

HRMS calcd. for $\mathrm{C}_{28} \mathrm{H}_{35} \mathrm{~N}_{2} \mathrm{O}_{6}\left([\mathrm{M}+\mathrm{H}]^{+}\right)$: 495.2490, found: 495.2496.

[(1R,8S,9s)-Bicyclo[6.1.0]non-4-yn-9-yl]methyl

[6-[[9-(diethylamino)-5-0xo-5H-

benzo[a]phenoxazin-2-yl]oxy]hexyl]carbamate (RBM5-143) 
To an ice-cooled solution of $N$-Boc protected amine RBM5-136 (100 mg, $0.19 \mathrm{mmol}$ ) in dry $\mathrm{CH}_{2} \mathrm{Cl}_{2}(6 \mathrm{~mL})$ was added dropwise neat TFA $(1.5 \mathrm{~mL})$. After stirring at $\mathrm{rt}$ for $2 \mathrm{~h}$ in the dark, the reaction mixture was concentrated to dryness to afford the corresponding crude amine trifluoroacetate $(81 \mathrm{mg})$. This crude was taken up in $\mathrm{CH}_{2} \mathrm{Cl}_{2}(10 \mathrm{~mL})$, followed by the sequential addition of $\mathrm{Et}_{3} \mathrm{~N}$ (93 $\mu \mathrm{L}, 0.67 \mathrm{mmol}$ ) and $p$-nitrophenol activated carbonate ester RBM5-14141 (60 $\mathrm{mg}, 0.19 \mathrm{mmol})$. After stirring overnight at $\mathrm{rt}$ in the dark, the reaction mixture was evaporated in vacuo and the residue was flash chromatographed (from 0 to $20 \%$ EtOAc in $\left.\mathrm{CH}_{2} \mathrm{Cl}_{2}\right)$ to give the desired carbamate RBM5-143 (104 mg, $\left.90 \%\right)$ as a shiny dark-red solid.

${ }^{1} \mathrm{H}$ NMR $\left(400 \mathrm{MHz}, \mathrm{CDCl}_{3}\right) \delta 8.21(\mathrm{~d}, J=8.7 \mathrm{~Hz}, 1 \mathrm{H}), 8.03(\mathrm{~d}, J=2.6 \mathrm{~Hz}, 1 \mathrm{H}), 7.60(\mathrm{~d}, J=$ $9.0 \mathrm{~Hz}, 1 \mathrm{H}), 7.15(\mathrm{dd}, J=8.7,2.6 \mathrm{~Hz}, 1 \mathrm{H}), 6.65(\mathrm{dd}, J=9.1,2.7 \mathrm{~Hz}, 1 \mathrm{H}), 6.45$ (d, $J=2.7 \mathrm{~Hz}$, $1 \mathrm{H}), 6.29(\mathrm{~s}, 1 \mathrm{H}), 4.70(\mathrm{br} \mathrm{s}, 1 \mathrm{H}), 4.19-4.11(\mathrm{~m}, 4 \mathrm{H}), 3.46$ (q, $J=7.1 \mathrm{~Hz}, 5 \mathrm{H}), 3.25-3.15$ (m, $2 \mathrm{H}), 2.34-2.16(\mathrm{~m}, 6 \mathrm{H}), 1.90-1.82(\mathrm{~m}, 2 \mathrm{H}), 1.67-1.30(\mathrm{~m}, 10 \mathrm{H}), 1.26(\mathrm{t}, J=7.0 \mathrm{~Hz}, 6 \mathrm{H})$, $0.97-0.87(\mathrm{~m}, 2 \mathrm{H})$.

${ }^{13} \mathrm{C}$ NMR $\left(101 \mathrm{MHz}, \mathrm{CDCl}_{3}\right) \delta 183.4,161.9,156.9,152.2,150.9,147.0,140.3,134.2,131.2$, $127.9,125.7,124.8,118.4,109.6,106.7,105.5,99.0,96.5,68.3,62.8,45.2,41.1,30.1,29.3$, $29.2,26.6,25.9,21.6,20.2,17.9,12.8$.

HRMS calcd. for $\mathrm{C}_{37} \mathrm{H}_{44} \mathrm{~N}_{3} \mathrm{O}_{5}\left([\mathrm{M}+\mathrm{H}]^{+}\right): 610.3275$, found: 610.3279 .

\section{d) Synthesis of doxdhCer by SPAAC reactions}

\section{Compound RBM5-160}

Compound RBM5-142 (7 mg, $15 \mu \mathrm{mol}$ ) was added to a stirred solution of RBM5-159 (9 mg, $12 \mu \mathrm{mol})$ in $\mathrm{CH}_{2} \mathrm{Cl}_{2}(4 \mathrm{~mL})$. After stirring overnight at $\mathrm{rt}$ in the dark, the reaction mixture was concentrated to dryness and the residue was flash chromatographed on silica gel (from 0 to 5 \% $\mathrm{MeOH}$ in $\mathrm{CH}_{2} \mathrm{Cl}_{2}$ ) to afford the desired SPAAC reaction adduct RBM5-160 (14 mg, 93 \%, inseparable mixture of diastereomers) as a dark-orange solid.

${ }^{1} \mathrm{H}$ NMR (400 MHz, DMSO-d6) (mixture of diastereomers) $\delta 9.54(\mathrm{~s}, 1 \mathrm{H}), 8.81(\mathrm{~s}, 1 \mathrm{H}), 8.63(\mathrm{t}$, $J=5.7 \mathrm{~Hz}, 1 \mathrm{H}), 8.50(\mathrm{~d}, J=9.1 \mathrm{~Hz}, 1 \mathrm{H}), 7.90(\mathrm{~d}, J=8.7 \mathrm{~Hz}, 1 \mathrm{H}), 7.49(\mathrm{~d}, J=8.5 \mathrm{~Hz}, 1 \mathrm{H})$, $7.14-7.04(\mathrm{~m}, 2 \mathrm{H}), 7.04(\mathrm{dd}, J=8.7,2.3 \mathrm{~Hz}, 1 \mathrm{H}), 6.41(\mathrm{~d}, J=9.3 \mathrm{~Hz}, 1 \mathrm{H}), 4.47$ (d, $J=6.1$ $\mathrm{Hz}, 1 \mathrm{H}), 4.18(\mathrm{t}, J=7.0 \mathrm{~Hz}, 2 \mathrm{H}), 4.07-3.96(\mathrm{~m}, 2 \mathrm{H}), 3.89$ (s, 3H), $3.66-3.58(\mathrm{~m}, 1 \mathrm{H}), 3.50$ $-3.39(\mathrm{~m}, 2 \mathrm{H}), 3.34-3.26(\mathrm{~m}, 2 \mathrm{H}), 3.26-3.17(\mathrm{~m}, 1 \mathrm{H}), 2.99-2.88(\mathrm{~m}, 4 \mathrm{H}), 2.77-2.61(\mathrm{~m}$, 
2H), $2.15-2.05(\mathrm{~m}, 3 \mathrm{H}), 2.01(\mathrm{t}, J=7.3 \mathrm{~Hz}, 2 \mathrm{H}), 1.73-1.60(\mathrm{~m}, 4 \mathrm{H}), 1.56-1.05(\mathrm{~m}, 60 \mathrm{H})$, $0.97(\mathrm{~d}, J=6.7 \mathrm{~Hz}, 3 \mathrm{H}), 0.94-0.82(\mathrm{~m}, 2 \mathrm{H})$.

HRMS calcd. for $\mathrm{C}_{68} \mathrm{H}_{105} \mathrm{~N}_{10} \mathrm{O}_{11}\left([\mathrm{M}+\mathrm{H}]^{+}\right):$1237.7959, found: 1237.7983 .

\section{Compound RBM5-161}

Compound RBM5-143 (10 mg, $15 \mu \mathrm{mol}$ ) was added to a stirred solution of RBM5-159 (10 $\mathrm{mg}, 13 \mu \mathrm{mol})$ in $\mathrm{CH}_{2} \mathrm{Cl}_{2}(4 \mathrm{~mL})$. After stirring overnight at $\mathrm{rt}$ in the dark, the reaction mixture was concentrated to dryness and the residue was flash chromatographed on silica gel (from 0 to $5 \% \mathrm{MeOH}$ in $\mathrm{CH}_{2} \mathrm{Cl}_{2}$ ) to afford the desired SPAAC reaction adduct RBM5-161 (16 mg, 88 $\%$, inseparable mixture of diastereomers) as a dark-red solid.

${ }^{1} \mathrm{H}$ NMR (400 MHz, DMSO- $d_{6}$ ) (mixture of diastereomers) $\delta 9.53$ (br s, $1 \mathrm{H}$ ), 8.48 (d, $J=8.9$ $\mathrm{Hz}, 1 \mathrm{H}), 8.03$ (d, $J=8.6 \mathrm{~Hz}, 1 \mathrm{H}), 7.94$ (d, $J=2.5 \mathrm{~Hz}, 1 \mathrm{H}), 7.64-7.59$ (m, 1H), 7.49 (d, $J=$ $8.6 \mathrm{~Hz}, 1 \mathrm{H}), 7.25(\mathrm{dd}, J=8.7,2.5 \mathrm{~Hz}, 1 \mathrm{H}), 7.10$ (t, $J=5.7 \mathrm{~Hz}, 1 \mathrm{H}), 6.81(\mathrm{~d}, J=9.2 \mathrm{~Hz}, 1 \mathrm{H})$, $6.64(\mathrm{~d}, J=2.4 \mathrm{~Hz}, 1 \mathrm{H}), 6.38(\mathrm{~d}, J=9.0 \mathrm{~Hz}, 1 \mathrm{H}), 6.18(\mathrm{~s}, 1 \mathrm{H}), 4.47$ (d, $J=6.1 \mathrm{~Hz}, 1 \mathrm{H}), 4.21$ $4.10(\mathrm{~m}, 4 \mathrm{H}), 4.02$ (d, $J=7.8 \mathrm{~Hz}, 2 \mathrm{H}), 3.67-3.57(\mathrm{~m}, 1 \mathrm{H}), 3.50$ (q, $J=7.0 \mathrm{~Hz}, 4 \mathrm{H}), 3.46-$ $3.39(\mathrm{~m}, 2 \mathrm{H}), 3.25-3.18(\mathrm{~m}, 1 \mathrm{H}), 3.15-3.04(\mathrm{~m}, 4 \mathrm{H}), 3.05-2.95(\mathrm{~m}, 2 \mathrm{H}), 2.94-2.86(\mathrm{~m}$, 2H), $2.78-2.59(\mathrm{~m}, 2 \mathrm{H}), 2.13-1.90(\mathrm{~m}, 7 \mathrm{H}), 1.83-1.73(\mathrm{~m}, 2 \mathrm{H}), 1.70-1.59(\mathrm{~m}, 4 \mathrm{H}), 1.54$ $-1.10(\mathrm{~m}, 58 \mathrm{H}), 0.96(\mathrm{~d}, J=6.7 \mathrm{~Hz}, 3 \mathrm{H}), 0.93-0.82(\mathrm{~m}, 2 \mathrm{H})$.

HRMS calcd. for $\mathrm{C}_{77} \mathrm{H}_{114} \mathrm{~N}_{11} \mathrm{O}_{10}\left([\mathrm{M}+\mathrm{H}]^{+}\right): 1352.8745$, found: 1352.8760 .

\section{FRET efficiency}

The FRET efficiencies of the donor-acceptor pairs were determined by comparing the integrated fluorescence intensities of the donor alone (D) and in the presence of the acceptor (DA). For this purpose, a series of solutions of the D compounds (RBM5-142 and RBM5-154) and the DA compounds (RBM5-160 and RBM5-161) was prepared such that the $A b s$ value at the corresponding $\lambda_{E x}$ was approximately between 0.01 and 0.1 , in order to avoid re-absorption effects. The absorption and emission spectra of each solution were recorded using a $1 \mathrm{~cm}$ path length quartz cuvette, as described above. Both D and DA compounds were analysed under the same conditions. The absorption and emission spectra of the DA compounds were subjected to deconvolution regression, as explained above, to isolate the spectra of the donor component (RBM5-160_donor and RBM5-161_donor). 
The integrated fluorescence intensity was then plotted against the $A b s$ value at the $\lambda_{E x}$ and adjusted to a linear regression function forced through the origin using GraphPad Prism version 7.00 for Windows (GraphPad Software Inc., La Jolla, CA, USA). Then, the FRET efficiency was calculated using Equation ¡Error! No hay texto con el estilo especificado en el documento..1, where $\operatorname{Grad}_{D}$ and $\operatorname{Grad}_{D A}$ are the slopes of the plots of the integrated fluorescence intensity $v s$ absorbance at the $\lambda_{E x}$ of the donor alone and the donor component (upon spectral deconvolution) in the presence of the acceptor, respectively.

$$
\begin{aligned}
& \text { Equation ¡Error! No hay } \\
& E=1-\frac{\operatorname{Grad}_{D A}}{\operatorname{Grad}_{D}} \quad \begin{array}{lllr}
\text { texto } & \text { con } & \text { el } & \text { estilo } \\
& \text { especificado } & \text { en } & \text { el }
\end{array} \\
& \text { documento..1 }
\end{aligned}
$$

\section{Biology}

\section{CerS assay}

To overexpress CerS5, $24 \mathrm{~h}$ before transfection, HEK293T cells were seeded in 6-well plates $\left(2 \times 10^{5}\right.$ cells per well). Then, cells were transfected with $2.5 \mu \mathrm{g} / \mathrm{well}$ of plasmid harbouring the human CerS5 gene using $0.01 \mathrm{mg} / \mathrm{mL}$ PEI in opti-MEM for $6 \mathrm{~h}$. Complete DMEM medium supplemented with 10\% FBS was added and cells were incubated for $48 \mathrm{~h}$. After transfection, cells were treated with RBM5-155 (10 $\mu \mathrm{M}$ final concentration) and $\omega$-azidopalmitic acid (500 $\mu \mathrm{M}$ final concentration) for $2 \mathrm{~h}$. The medium was remove and the cells were washed with 400 $\mu \mathrm{L}$ PBS. UPLC-MS analysis was performed as mentioned below

\section{Lipid extraction}

Cell pellets were suspended with $100 \mu \mathrm{L}$ of $\mathrm{H}_{2} \mathrm{O}$ and mixed with $750 \mu \mathrm{L}$ of methanol: chloroform, 2:1. Samples were heated at $48^{\circ} \mathrm{C}$ overnight and next day, $75 \mu \mathrm{L}$ of $1 \mathrm{M} \mathrm{KOH}$ in methanol were added, followed by $2 \mathrm{~h}$ incubation at $37^{\circ} \mathrm{C}$. Afterwards, the saponification was neutralised with $75 \mu \mathrm{L}$ of $1 \mathrm{M}$ acetic acid and solvent was removed using a Speed Vac Savant SPD131DDA (Thermo Scientific).

\section{UPLC-MS analysis}

Lipid extracts, fortified with internal standards ( $N$-dodecanoylsphingosine, $N$-dodecanoylglucosylsphingosine, $N$-dodecanoylsphingosylphosphorylcoline and C17-sphinganine $0.2 \mathrm{nmol}$ each) were solubilised in $150 \mu \mathrm{L}$ of methanol. Samples were then centrifuged at 9,300 
g for $3 \mathrm{~min}$ and $130 \mu \mathrm{L}$ of the supernatant were injected to a Waters Aquity UPLC system connected to a Waters LCT Premier Orthogonal Accelerated Time of Flight Mass Spectrometer (Waters, Milford, MA, USA) operated in positive electrospray ionisation mode. Full scan spectra from 50 to $1500 \mathrm{Da}$ were acquired and individual spectra were summed to produce data points every $0.2 \mathrm{~s}$. Mass accuracy and reproducibility were maintained by using an independent reference spray by the LockSpray interference. The analytical column was a $100 \mathrm{~mm} \times 2.1 \mathrm{~mm}$ i.d., 1.7 $\mu \mathrm{m}$ C8 Acquity UPLC BEH (Waters). The two mobile phases were phase A: methanol/water/formic acid (74/25/1 v/v/v); phase B: methanol/formic acid $(99 / 1 \mathrm{v} / \mathrm{v})$, both also contained $5 \mathrm{mM}$ ammonium formate. A linear gradient was programmed $-0.0 \mathrm{~min}$ : $80 \%$ B; 3 min: $90 \%$ B; 6 min: $90 \%$ B; 15 min: $99 \%$ B; 18 min: $99 \%$ B; 20 min: $80 \%$ B. The flow rate was $0.3 \mathrm{~mL} \mathrm{~min}^{-1}$.

\section{Supporting Material}

Representative NMR spectra and fluorescence studies

\section{References}

(1) Carreira, A. C.; Santos, T. C.; Lone, M. A.; Zupančič, E.; Lloyd-Evans, E.; de Almeida, R. F. M.; Hornemann, T.; Silva, L. C. Prog. Lipid Res. 2019, 75 (May), 100988.

(2) Hannun, Y. A.; Obeid, L. M. Nat. Rev. Mol. Cell. Biol. 2008, 9 (2), 139-150.

(3) Alonso, A.; Goñi, F. M. Annu. Rev. Biophys. 2018, 47 (1), 633-654.

(4) Hannun, Y. A. Science 1996, 274 (5294), 1855-1859.

(5) Jenkins, G. M.; Richards, A.; T., W.; Maos, C.; Obeid, L.; Hannun, Y. A. J. Biol. Chem. 1997, 272, 32566-32572.

(6) Sietsma, H.; Veldman, R. J.; Kok, J. W. J. Membr. Biol. 2001, 181, 153-162.

(7) Cho, S. M.; Kwon, H. J. Arch. Pharm. Res. 2019, 42 (3), 232-243.

(8) Okazaki, T.; Bell, R. M.; Hannun, Y. A. J. Biol. Chem. 1989, 264 (32), 19076-19080.

(9) Venable, M. E.; Lee, J. Y.; Smyth, M. J.; Bielawska, A.; Obeid, L. M. J. Biol. Chem. 1995, 270 (51), 30701-30708.

(10) Marasas, W. F. O. Environ. Health Perspect. 2001, 109 (suppl 2), 239-243.

(11) Mullen, T. D.; Hannun, Y. A.; Obeid, L. M. Biochem J 2012, 441, 789-802. 
(12) Kurz, J.; Parnham, M. J.; Geisslinger, G.; Schiffmann, S. Trends Mol. Med. 2018, 25 (1), 20-32.

(13) Stiban, J.; Tidhar, R.; Futerman, A. H. Adv Exp Med Biol 2010, 688, 60-71.

(14) Park, J. W.; Park, W. J.; Futerman, A. H. Biochim. Biophys. Acta - Mol. Cell Biol. Lipids 2014, 1841 (5), 671-681.

(15) Merrill Jr., A. H.; Sullards, M. C.; Allegood, J. C.; Kelly, S.; Wang, E. Methods 2005, $36(2), 207-224$.

(16) Grösch, S.; Schiffmann, S.; Geisslinger, G. Prog. Lipid Res. 2012, 51 (1), 50-62.

(17) Nieves, I.; Sanllehí, P.; Abad, J.-L. L.; Fabriàs, G.; Casas, J.; Delgado, A. In Bioactive Sphingolipids in Cancer Biology and Therapy; Hannun, Y., Luberto, C., Obeid, L., Mao, C., Eds.; Springer International Publishing: Cham, 2015; pp 437-469.

(18) Abad, J. L.; Nieves, I.; Rayo, P.; Casas, J.; Fabriàs, G.; Delgado, A. J. Org. Chem. 2013, 78 (12), 5858-5866.

(19) Mina, J. G.; Mosely, J. A.; Ali, H. Z.; Denny, P. W.; Steel, P. G. Org Biomol Chem 2011, 9 (6), 1823-1830.

(20) Hostetler, E. D.; Fallis, S.; McCarthy, T. J.; Welch, M. J.; Katzenellenbogen, J. A. J. Org. Chem. 1998, 63 (4), 1348-1351.

(21) Mandal, P. K.; McMurray, J. S. J. Org. Chem. 2007, 72 (17), 6599-6601.

(22) Bhabak, K. P.; Hauser, A.; Redmer, S.; Banhart, S.; Heuer, D.; Arenz, C. ChemBioChem 2013, 14 (9), 1049-1052.

(23) In this sense, our early attempts to obtain the free amine by washing the organic extracts with $0.5 \mathrm{M} \mathrm{NaOH}$ resulted in the formation of unidentified by-products, as evidenced by the appearance of new UV-active spots in the TLC plate, and a poor recovery after column chromatography of the crude.

(24) Xue, Y.; Zimmt, M. B. J. Am. Chem. Soc. 2012, 134 (10), 4513-4516.

(25) Matikainen, J.; Kaltia, S.; Ala-Peijari, M.; Petit-Gras, N.; Harju, K.; Heikkilä, J.; Yksjärvi, R.; Hase, T. Tetrahedron 2003, 59 (4), 567-573.

(26) Zerkowski, J. A.; Nuñez, A.; Strahan, G. D.; Solaiman, D. K. Y. J. Am. Oil Chem. Soc. 2009, $86(11), 1115-1121$.

(27) Morales-Serna, J. A.; Boutureira, O.; Serra, A.; Isabel Matheu, M.; Díaz, Y.; Castillón, S. Eur. J. Org. Chem. 2010, No. 14, 2657-2660. 
(28) Hang, H. C.; Geutjes, E.-J.; Grotenbreg, G.; Pollington, A. M.; Bijlmakers, M. J.; Ploegh, H. L. J. Am. Chem. Soc. 2007, 129 (10), 2744-2745.

(29) Pérez, A. J.; Bode, H. B. J. Lipid Res. 2014, 55 (9), 1897-1901.

(30) Walter, T.; Schlegel, J.; Burgert, A.; Kurz, A.; Seibel, J.; Sauer, M. Chem. Commun. (Camb). 2017, 53 (51), 6836-6839.

(31) Devadas, B.; Lu, T.; Katoh, A.; Kishore, N. S.; Wade, A. C.; Mehta, P. P.; Rudnick, D. A.; Bryant, M. L.; Adams, S. P.; Li, Q. J. Biol. Chem. 1992, 267 (11), 7224-7239.

(32) Ries, O.; Carnarius, C.; Steinem, C.; Ducho, C. Med. Chem. Comm. 2015, 6 (5), 879886.

(33) Bieniarz, C.; Ramakrishna, K. V.; Kelly, T. P. J. Label. Compd. Radiopharm. 2000, 43 (3), 243-250.

(34) Thompson, A. S.; Humphrey, G. R.; DeMarco, A. M.; Mathre, D. J.; Grabowski, E. J. J. J. Org. Chem. 1993, 58 (22), 5886-5888.

(35) Crombie, L. J. Chem. Soc. 1955, No. 3510, 3510.

(36) Yang, Z.; He, Y.; Lee, J. H.; Chae, W. S.; Ren, W. X.; Lee, J. H.; Kang, C.; Kim, J. S. Chem. Commun. 2014, 50 (79), 11672-11675.

(37) Evans, H. L.; Nguyen, Q.-D.; Carroll, L. S.; Kaliszczak, M.; Twyman, F. J.; Spivey, A. C.; Aboagye, E. O. Chem. Commun. 2014, 50 (67), 9557-9560.

(38) Yang, J.; Šečkutė, J.; Cole, C. M.; Devaraj, N. K. Angew. Chem. Int. Ed. 2012, 51 (30), $7476-7479$.

(39) Hochstrasser, R. M.; King, D. S.; Smith, A. B. J. Am. Chem. Soc. 1977, 99 (12), $3923-$ 3933.

(40) Beckmann, H. S. G. G.; Niederwieser, A.; Wiessler, M.; Wittmann, V. Chem. Eur. J. 2012, 18 (21), 6548-6554.

(41) Dommerholt, J.; Schmidt, S.; Temming, R.; Hendriks, L. J. A.; Rutjes, F. P. J. T.; van Hest, J. C. M.; Lefeber, D. J.; Friedl, P.; van Delft, F. L.; van Hest, J. C.; Lefeber, D. J.; Friedl, P.; van Delft, F. L. Angew. Chem. Int. Ed. 2010, 49 (49), 9422-9425.

(42) Tosi, I. Model systems for artificial photosynthesis: calix[4]arenes functionalized with chromophoric units for energy and charge transfer, Doctoral thesis, Universita' degli studi di Parma, 2015.

(43) Smith, S.; Witkowski, A.; Joshi, A. K. Prog. Lipid Res. 2003, 42 (4), 289-317. 
(44) McCune, S. A.; Harris, R. A. J. Biol. Chem. 1979, 254 (20), 10095-10101.

(45) Halvorson, D. L.; McCune, S. A. Lipids 1984, 19 (11), 851-856.

(46) Vance, D.; Goldberg, I.; Mitsuhashi, O.; Bloch, K.; Ōmura, S.; Nomura, S. Biochem. Biophys. Res. Commun. 1972, 48 (3), 649-656.

(47) Lahiri, S.; Lee, H.; Mesicek, J.; Fuks, Z.; Haimovitz-Friedman, A.; Kolesnick, R. N.; Futerman, A. H. FEBS Lett. 2007, 581 (27), 5289-5294.

(48) Lahiri, S.; Futerman, A. H. J. Biol. Chem. 2005, 280 (40), 33735-33738.

(49) Rai, A. N.; Basu, A. Org. Lett. 2004, 6 (17), 2861-2863.

(50) Ibuka, T.; Habashita, H.; Otaka, A.; Fujii, N.; Oguchi, Y.; Uyehara, T.; Yamamoto, Y. J. Org. Chem. 1991, 56 (14), 4370-4382. 